\title{
MOVIMENTO SOCIAL JUDEU QUE RESULTOU NO CRISTIANISMO PRIMITIVO: DA PREGAÇÃO DA “BOA NOVA” POR CRISTO, NOS TERRITÓRIOS DA PALESTINA DO SÉCULO I, À INTERPRETAÇÃO DO SEU DISCURSO, NO SÉCULO XXI
}

\author{
JEWISH SOCIAL MOVEMENT THAT RESULTED IN PRIMITIVE CHRISTIANITY: FROM THE "GOOD \\ NEWS" PREACHING BY CHRIST, IN PALESTINIAN TERRITORIES FROM THE 1ST CENTURY TO \\ THE INTERPRETATION OF HIS SPEECH, IN THE 21ST CENTURY
}

Beatriz Maria Soares PONTES 1

Artigo recebido em 12/05/2018 e aceito em 16/07/2018

Palavras-chave:

Palestina;

Modos de Produção

Pré-Capitalistas;

O Território

Palestino;

A Pregação da "Boa

Nova";

A Reinterpretação

do Discurso de Jesus.

\section{R E S U M O}

De acordo com a temática proposta, pretende-se estudar, em primeiro lugar, os modos de produção pré-capitalistas tributário e escravagista. A seguir, será efetivada uma análise da Palestina, no século I, privilegiando-se a formação econômica, a estrutura da sociedade de classes em vigência, a estratificação social, o sistema político e, finalmente, a estrutura do Estado que persistia na Palestina desta época, o poder e as correntes ideológicas. Continuando, será discutida a natureza da pregação de Cristo, contemplando, não apenas, os territórios por Ele percorridos na Palestina, senão também, o conteúdo do seu próprio discurso à época em que viveu. Finalmente, será analisado e interpretado o discurso de Jesus, no século XXI. Dessa forma, pretende-se explicar como um movimento social que, no início, pretendeu questionar a forma como o judaísmo era levado a termo, no decurso da vida de Cristo, transformou-se, paulatinamente, no que, depois, foi reconhecido como o cristianismo primitivo.

\begin{abstract}
A B S T R A C T
According to the proposed theme, it's intended to study, in the first place, the precapitalist modes of production, tributary and slavery. Hereafter, an analysis of Palestine will take place in the first century, privileging economic formation, the structure of class society in force, social stratification, the political system, and finally the state structure that persisted in Palestine in that time, the power and ideological currents. Continuing, Christ's preaching nature will be discussed, contemplating, not only, the territories he has traveled in Palestine, but also the content of his own discourse at the time in which he lived. Finally, the discourse of Jesus will be analyzed and interpreted in the 21st century. In this way, its intended to explain how a social movement that, at the beginning, tried to question the way in which the Judaism was carried out, and, during the life of Christ, was transformed, gradually, in what later was recognized as the primitive Christianity.
\end{abstract}

\footnotetext{
1 Profa. Dra. / Livre-Docente pela UNESP (2008), atualmente é Profa. Titular aposentada da UFRN. Atualmente, é Professora Colaboradora do Grupo de Pesquisas Movimentos Sociais e Dinâmicas Espaciais (UFPE) e do Grupo de Pesquisas Geopolítica e Território, do Centro de Estudos em Geopolítica e Relações Internacionais (CENEGRI). Presentemente, está envolvida com pesquisas relativas à Geopolítica do Oriente Médio e do Extremo Oriente, com particular ênfase à China. E-mail: lavbiapontes@hotmail.com.
} 


\section{INTRODUÇÃO}

Quando Jesus nasceu, toda a região mediterrânea estava sob o firme controle de Roma. A Palestina era, mais uma vez, região fronteiriça e elo vital nas comunicações entre uma grande potência e as remotas províncias de seu império. Nem Jesus, nem qualquer outro judeu podia escapar da influência de Roma.

O segredo da conquista do resto do mundo mediterrâneo por Roma estava na forma como seus cidadãos encaravam o serviço militar.

Na primeira parte da expansão, todo cidadão de Roma era recrutado para o exército em sistema de revezamento. De bom grado, aceitavam o tipo de disciplina bem diferente necessário a um serviço militar eficaz e eram chefiados em combate pelos magistrados que eles mesmos haviam elegido para o cargo. Assim, o exército era uma "milícia" civil, com procedimentos claros e coerentes para todas as situações militares, desde a instalação do acampamento, até a investida contra uma praça-forte.

Todo cidadão era treinado nesses procedimentos militares, de modo que o conscrito, durante o período de serviço, ou o magistrado que exercesse o cargo naquele ano, podia assumir o poder sem grande confusão. Tudo o que era preciso para a eficácia dessa força era mobilidade, garantida pelo Estado romano, a partir de 312 a.C., com a construção da primeira das grandes estradas militares, a Via Ápia. Estas acabaram por formar uma vasta rede de vias de comunicação que ligavam todas as partes do Império Romano (RHYMER, 1995).

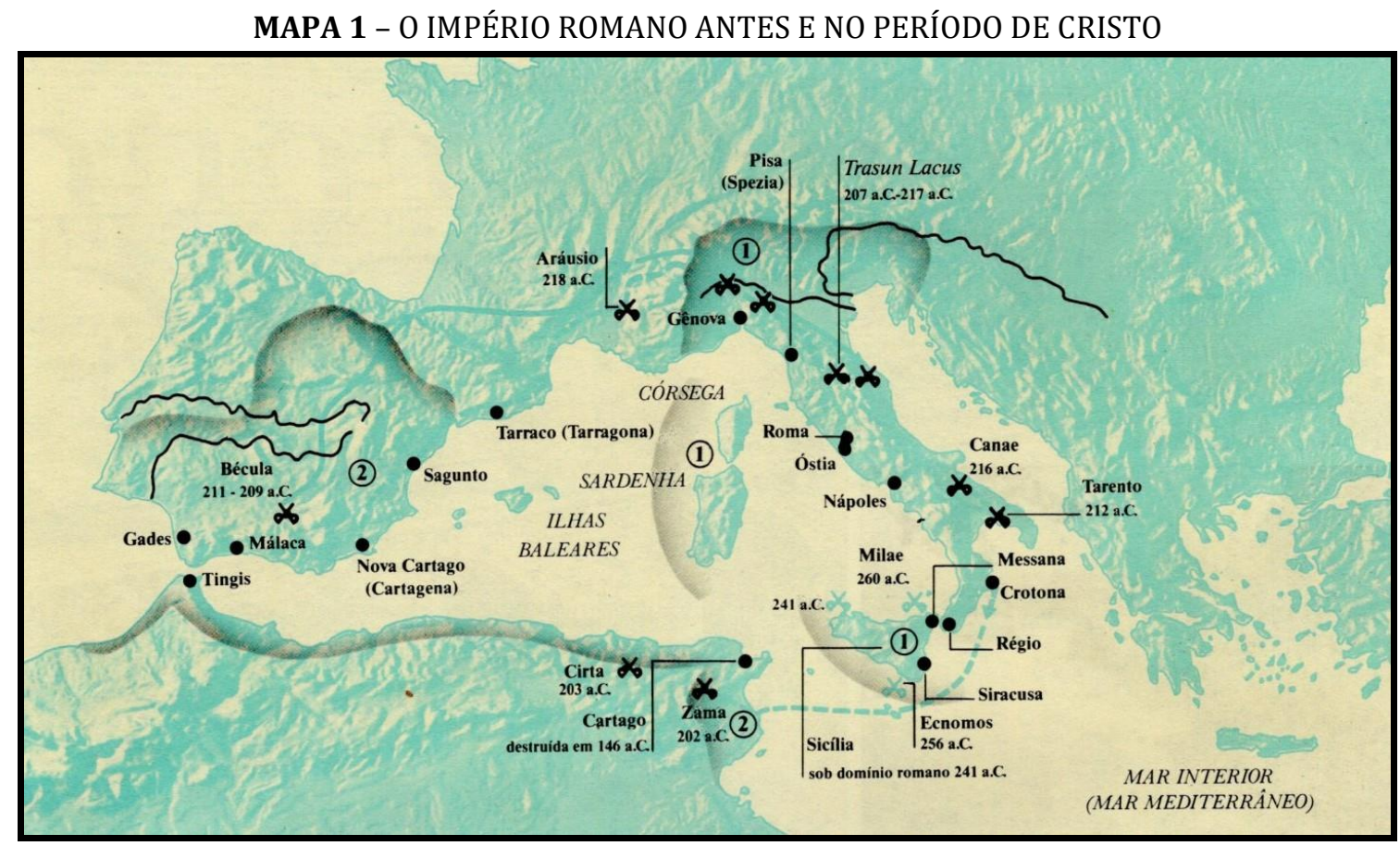

Fonte: Rhymer, p. 72, 1990. 
Dentro deste contexto, pretende-se estudar, de acordo com a temática proposta, em primeiro lugar, os modos de produção pré-capitalistas tributário e escravagista. A seguir, será efetivada uma análise da Palestina, no século I, privilegiando-se a formação econômica, a estrutura da sociedade de classes em vigência, a estratificação social, o sistema político e, finalmente, a estrutura do Estado que persistia na Palestina desta época, o poder e as correntes ideológicas. Continuando, será discutida a natureza da pregação de Cristo, contemplando, não apenas, os territórios por Ele percorridos na Palestina, senão também, o conteúdo do seu próprio discurso à época em que viveu. Finalmente, será analisado e interpretado o discurso de Jesus, no século XXI.

Dessa forma, pretende-se explicar como um movimento social que, no início, pretendeu questionar a forma como o judaísmo era levado a termo, no decurso da vida de Cristo, transformou-se, paulatinamente, no que, depois, foi reconhecido como o cristianismo primitivo.

Para finalizar, deve-se ressaltar que, o que está consignado neste estudo é da inteira responsabilidade de sua autora, não se atribuindo nenhuma responsabilidade a pessoas, grupos de pessoas ou comunidades, bem como instituições religiosas.

\section{OS MODOS DE PRODUÇÃO PRÉ-CAPITALISTAS TRIBUTÁRIO E ESCRAVAGISTA}

O modo de produção tributário é uma forma social diretamente derivada das sociedades tribais. É constituído pelas antigas comunidades aldeãs, que se viram cobertas por uma "unidade" superior, instância política de exploração das primeiras por intermédio da aplicação de um tributo. A organização da economia repousaria no fato de que a instância política disporia da propriedade real do meio de produção, cujo uso teria sido mantido pelas comunidades aldeãs.

A concordância observada entre os resultados de pesquisas sobre certas sociedades sulasiáticas e os resultados de trabalhos realizados sobre as formações sociais africanas e do Sudeste asiático levou a se pensar que as relações sociais de produção que se estabeleceram entre a instância política e as entidades sociais das aldeias construíram-se, unicamente, em função da arrecadação do tributo. Entretanto, o tributo seria apenas um dos elementos de uma relação de intercâmbio quase contratual entre o grupo no poder e os grupos de base. 0 outro elemento seria a garantia de proteção que a instância política devia assegurar às comunidades aldeãs. Contudo, não se pode compreender esse tipo de relação, confinando as análises no seio de cada uma das formações sociais, como se suas estruturas tivessem que ser produto de fatores endógenos. Acontece que, na explicação da gênese do fenômeno parecem não levar suficientemente em consideração as inter-relações econômicas de tipo mercantil da Ásia Menor, do Egito e da região da África, banhada pelo oceano Índico as quais, na Antiguidade, estendiam-se até o sul da Ásia, ao longo das rotas marítimas que ligavam a Índia à China. A proteção desses intercâmbios comerciais é que está na origem da emergência dos novos poderes 
políticos que passaram a estabelecer o seu controle no interior, onde os clãs de outrora continuaram a se reproduzir, segmentando-se, progressivamente em função de seu crescimento demográfico.

Nesse modo de produção, portanto, o sistema dominante é o sistema político, pois é a partir da instância política que se organiza a vida material. Assim, é a estrutura das relações de poder que preenche, simultaneamente, a função de relações sociais de produção. Nas unidades sociais constituídas pelas aldeias, a organização da economia manteve-se inalterada: cada unidade produtora dispõe do meio de produção, em virtude de sua pertença à comunidade, estruturada segundo as relações de parentesco.

0 aparecimento da instância política recolhendo tributos está na origem do desenvolvimento de uma sociedade de classes, cuja manifestação mais perceptível é a dicotomia entre o rural e o urbano; as cidades, onde se aglomeram os consumidores do tributo, se constituem de modo autônomo, em relação às regiões rurais produtoras.

Nesse modo de produção, a contradição maior situa-se ao nível da oposição entre a manutenção das comunidades, por um lado e, a negação da comunidade pelo Estado, por outro. É essa contradição que a ideologia procura reduzir, apresentando o poder político como expressão de uma comunidade superior globalizadora do conjunto das entidades locais. Entretanto, o discurso ideológico legitimador do poder não tem conotações religiosas, já que o caráter quase contratual permanece no centro das representações. Então, o poder político é associado à ideia do "Pai de todos", o "Rei protetor", que garante a justiça. Quando, porém, ao contrário, a base dessas representações tende a se desfazer - quando, por exemplo, as formações sociais de tipo tributário conhecem longos períodos de paz e prosperidade econômica, fazendo com que a cobrança do tributo apareça como fruto do arbítrio - então, a sansão ideológica do poder procura se expressar em termos religiosos. A instância política, o Rei, é apresentado como um super-homem, intermediário entre Deus e os homens, descendendo em função direta do casal sol/lua ou ainda sob outras formas, conforme os sistemas religiosos.

Já a religião das entidades aldeãs pode ser encontrada tal como fora produzida na sociedade tribal, à exceção do totem, cujo significado desaparece com a segmentação do clã em grupos mais autônomos. Entretanto, a religião, que ocupa uma posição dominante no campo ideológico das entidades aldeãs, adquiri amiúde uma nova função, a de constituir um fator central na definição da identidade dos grupos de base (os antigos clãs), que perderam uma parte da sua função política, mas que ainda conservam uma grande importância como grupos de afinidade cultural.

No que concerne ao modo de produção escravagista, a principal característica deste modo de produção reside no fato de que o trabalhador escravo faz parte dos meios de produção. Assim, o modo só pode existir quando o conceito de propriedade privada se generalizou e se desenvolveram as desigualdades entre os proprietários. Foi, então, que apareceu a escravidão por dívida. A aceleração do processo foi geralmente consequência das guerras, com os prisioneiros, constituindo, então, uma mão 
de obra servil em uma economia agrária. No caso da escravatura patriarcal, o produto de seu trabalho entra no circuito das transferências não mercantis próprias da comunidade.

Todavia, esse modo de produção só ganha sua maior amplitude quando o produto do trabalho escravo passou a entrar no circuito dos intercâmbios mercantis. Desse modo, o crescimento da demanda implica no aumento da produção e, portanto, da força de trabalho, que se torna assim, objeto de intercâmbio mercantil. Esta última forma foi típica das sociedades grega e romana. Contudo, a organização da economia nesse modo de produção é marcada por sua dependência do exterior, ao mesmo tempo no campo da demanda (comunidade dos intercâmbios mercantis) e ao nível da origem da mão de obra (prisioneiros de guerra). É isso o que explica, por um lado, a sua precariedade e, por outro, o fato de que essa forma de sociedade não desemboca nunca na constituição estável de uma sociedade de classe.

É mais difícil estabelecer a teoria da função social da religião em um modo de produção escravagista, do que em outros. No caso concreto mais típico, a sociedade romana, o sistema religioso é bastante complexo: por um lado, porque foi incontestavelmente influenciado pela sucessão das formas políticas (Reino, República, Império); por outro, porque integrou em seu quadro elementos de religiões estrangeiras, devido ao caráter cosmopolita dos grupos sociais.

Embora se possa notar alguma mudança entre a religião de caráter doméstico da Roma dos reis e a religião em que o imperador é divinizado, não se encontra uma leitura religiosa da escravatura propriamente dita. E, no entanto, a relação de produção é transparente, pois, o escravo, as mais das vezes estrangeiro, constitui objeto de intercâmbio mercantil (HOUTART, 1982).

\section{A PALESTINA, NO SÉCULO I.}

\subsection{A Formação Econômica}

O sistema econômico deriva da organização da subsistência material. E, essa organização é resultante da estruturação de dois sistemas de relações: a relação entre os agentes produtores e os meios de produção, por um lado e, a relação entre os proprietários do sobreproduto e os meios de produção, por outro. É com base nessas duas relações que se estrutura um determinado modo de produção. Assim, que características tinham essas relações e como se estruturavam elas, na Palestina, na época de Jesus?

Ao nível das forças produtivas, isto é, da relação entre força de trabalho e meios de produção, a Palestina caracterizava-se por um grau de desenvolvimento relativamente baixo. Duas grandes atividades econômicas constituíam a base sobre a qual repousava o sistema produtivo judeu: a agricultura e pecuária (incluindo a pesca) e, por outro lado, a produção artesanal. Nos dois setores, o 
grau de desenvolvimento das forças produtivas era mínimo: arados sem rodas, técnicas de pesca relativamente empíricas, produção artesanal primitiva.

A dualidade do sistema produtivo desembocou, não apenas, numa dualidade econômica, mas também, numa dualidade social, política e religiosa. Em torno da agricultura, da pecuária e da pesca, estruturavam-se pequenas comunidades que viviam em pequenas aldeias ou "vilas". Já a atividade artesanal crescia e se desenvolvia sob a proteção das cidades. Essa dualidade iria determinar e consolidar uma divisão geográfica já tradicional: a Galileia e a Judeia, o Norte e o Sul. A Galileia "era inteiramente coberta de plantações, assemelhando-se a um imenso jardim". Essa região, rica em agricultura e pecuária, base da alimentação e da economia da Palestina, fez com que se considerasse que "no tempo de Jesus, os judeus eram um povo essencialmente agrícola, mas não exclusivamente". Por outro lado, falando de Jerusalém e dos centros urbanos, observou-se que na época, a forma típica de atividade profissional era o ofício artesanal. Efetivamente, os judeus eram artesãos hábeis e aplicados, como revela a documentação da época, que chega a falar de 43 categorias de artesãos.

A agricultura (e pecuária) e artesanato são atividades que se constroem de modo diferente do ponto de vista das relações de produção. No setor agrícola, a maior parte da população era constituída de pequenos proprietários. A divisão do trabalho não era muito desenvolvida e eles tinham que pagar um tributo ao Estado. Ao lado dessa massa, figuravam os grandes proprietários fundiários, que empregavam a força de trabalho de diaristas e escravos. Frequentemente, esses proprietários viviam nas cidades, deixando a direção da propriedade a um administrador. Esse tipo de grandes proprietários era mais numeroso na Judeia, do que na Galileia. Com o capital assim obtido, eles emprestavam dinheiro aos pequenos proprietários empobrecidos, hipotecando os bens de seus devedores. Esse sistema permitia a acumulação das grandes propriedades em algumas famílias. Por fim, foi com base nessa fração da classe dominante que se criou o mercado agrícola e o comércio hebreu, em geral.

Um terceiro setor da população agrícola era constituído por camponeses que não possuíam terras, mas, trabalhavam toda a sua vida para proprietários que lhes arrendavam parcelas. 0 pagamento podia ser efetuado seja por uma quantidade fixa de produtos, seja por meio de dinheiro. Uma variante desse setor era constituída pela presença de pequenos agricultores, semelhantes ao "colono" romano. Eles recebiam do proprietário da terra as sementes, os instrumentos de trabalho, etc. Cultivavam o solo e, a título de salário, guardavam uma parte do produto (a metade, 1/3 ou 1/4). 0 antagonismo entre eles e os proprietários era visível.

No setor artesanal, a população produtiva era representada muito mais por trabalhadores autônomos. Nesse tipo de empreendimento, o produtor possuía todos os meios de produção, fabricava os produtos e, sem mais circulação de bens, entregava-os diretamente aos consumidores, os clientes. 0 setor artesanal, portanto, estruturava-se em torno de uma produção familiar. Famílias inteiras, sobretudo, aquelas cujos membros eram hábeis operários, guardavam zelosamente os segredos de sua 
arte. Em cada ofício, a norma era a sucessão de pais para filhos, como mostram as expressões da época: "ele era carpinteiro, filho de carpinteiro ou carpinteiro". Além da atividade familiar, havia também pequenas unidades artesanais que davam trabalho a um número mais ou menos importante de operários.

Esse proletariado artesanal, juntamente com a mão de obra empregada no campo, formava a mais importante massa laboriosa da Palestina. Ao seu lado, encontravam-se os escravos, divididos em duas categorias: os escravos hebreus e aqueles que eram chamados escravos cananeus ou estrangeiros. Os escravos cobriam um amplo setor da atividade produtiva e de serviços. Ao lado do escravo preceptor e professor ou de escravas cabelereiras, cantoras e dançarinas, podiam-se encontrar homens e mulheres escravos trabalhando como barbeiros, fabricantes de colares, entalhadores de pedra e madeira, padeiros, açougueiros, etc.

Embora essa massa de escravos não fosse tão numerosa e importante como a de Roma, do ponto de vista econômico e sociopolítico, era comprada e vendida por contrato escrito, como no caso das mercadorias e dos animais. O sistema de relações entre o escravo e o senhor já é bastante conhecido, dispensando maiores comentários.

Saindo das atividades produtivas e passando à circulação, encontra-se o terceiro setor fundamental da atividade econômica da Palestina, na época de Jesus: o comércio.

O comércio tinha a cidade como o seu polo de desenvolvimento e o setor dos grandes proprietários fundiários como propulsor. Nas aldeias, o sistema de circulação era realizado, pois, os termos de intercâmbio eram regidos pela troca. Nas cidades, ao contrário, o comércio era interno. Os judeus haviam aprendido as práticas comerciais com os fenícios; depois, a dominação grega, seguida da romana, marcou ainda mais o desenvolvimento comercial dos judeus.

A atividade mercantil era próspera, não somente, em nível internacional, a partir da política comercial, instaurada por Simão Asmoneu, quando da conquista das cidades costeiras, seguida por João Hircano e Alexandre Janeu, garantindo ao país um canal para o mar, mas também, um desenvolvimento ao nível interno. Jerusalém e todas as cidades da Judeia e da Galileia, estavam cheias de estabelecimentos de mercadores e artesãos: feiras de animais, carnes, fazendas, especiarias, etc., bem como oficinas de sapatos, objetos de artesanato, tinturas, etc. Toda a atividade comercial, inclusive as importações e exportações era controlada por um sistema de impostos que se tornaria insuportável na época de Herodes. Foi nessa época que o nome "publicano" tornou-se sinônimo de ladrão e assassino. No tempo dos procuradores romanos, o sistema de impostos tornou-se ainda mais pesado. Por outro lado, o pagamento de direitos alfandegários era uma outra forma de extorsão. Cada cidade possuía uma fronteira aduaneira. Assim, de cada vez que se era detido, em terra ou no mar, era preciso pagar os direitos. Essa política fiscal fazia com que o Estado aparecesse como um dos grandes monopolizadores do sobretrabalho: o Estado judeu, em primeiro lugar e o Estado romano, em segundo. Assim, é importante examinar o seu papel econômico. 
Jeremias, assinala que a presença do aparelho de Estado em Jerusalém tinha uma dupla influência sobre a economia, não somente da cidade, mas também, do país: uma influência direta na medida em que os reis levavam uma vida faustosa e um papel indireto, em virtude do centro político ser um polo de atração para o capital nacional. 0 Estado era um grande empregador: reconstrução do Templo, construção de palácios, monumentos, aquedutos, muralhas, etc. Não obstante, formando uma unidade com o Estado, o Templo revestia-se de grande importância econômica. Através da coleta de impostos, o Templo recuperava para o Estado uma boa parte do sobreproduto social do povo judeu. Além disso, era um centro comercial de primeira ordem, não somente, em virtude das peregrinações que faziam com que inúmeras atividades comerciais se desenvolvessem em torno do Templo, mas também, porque os animais que deviam ser sacrificados e o sistema de oferendas implicavam toda uma complexa atividade comercial. Cada fiel, por exemplo, devia comprar diversos animais e frutos para oferecer em sacrifício: esses elementos do sacrifício eram vendidos por representantes do Templo, que por seu turno, os recebia como oferendas. Desse modo, o tesouro do Templo, administrado pelos Sumos Sacerdotes, com uma ampla máquina burocrática, era, na verdade, o Tesouro do Estado. Pertencia às finanças públicas, das quais os sacerdotes, teoricamente, simples administradores, obtinham, não somente, a sua renda regular, mas também, a sua fonte de prestígio e poder político. Por fim, como o Estado, o Templo desempenhava também o papel de um grande empregador de mão de obra qualificada, sobretudo, no setor artesanal. Jeremias afirma que o Templo representava um "centro" de trabalho que, juntamente com os príncipes das famílias herodianas criou um proletariado artesanal que era o melhor remunerado da Palestina, com uma tradição familiar e um prestígio social que o distinguiria não só do proletariado agrícola, como da massa de artesãos instalados por conta própria.

Não seria exagerado dizer que o Templo era o mais poderoso aparelho estatal, exercendo uma função de centralização do poder e da dominação exercidos sobre o povo. Esse papel central do Templo, aparelho ideológico e econômico ao mesmo tempo, revelou um dos aspectos do modo de produção tributário.

Finalmente, deve-se considerar o caráter colonial da economia judia. O Estado romano, que ocupava o país, obtinha a outra parte importante do sobretrabalho palestino. A Judeia (apenas) pagava seiscentos talentos por ano aos romanos, o que equivalia a seis milhões de denários; um denário representava uma jornada de salário agrícola. Como já se indicou, o sistema de recolhimento baseavase na complexa rede de impostos: o tributum, imposto pessoal e imposto fundiário; a amora, contribuição anual, frequentemente em espécie, destinada a assegurar as necessidades das tropas das guarnições romanas; o publicum, imposto direto sobre a compra e venda de todos os produtos, mesmo os de primeira necessidade. Ainda por cima e por causa dessa situação de dominação econômica, a dominação cultural e política penetrava em todos os domínios da vida judia. 
Em resumo, pode-se concluir que, do ponto de vista econômico, a formação social da Palestina, na época de Jesus, caracterizava-se como o resultado da ação superposta de dois modos de produção. 0 setor das aldeias, formando as unidades de base, articuladas com o Estado-Templo, que se apropriava de seu excedente, constituía o modo de produção tributário. Ademais, o setor mercante, desenvolvido nas cidades e tendo em sua retaguarda o apoio da grande propriedade e do setor artesanal, aproximava-se mais das formas mercantis comuns, no modo de produção escravagista romano, com a diferença de que a escravidão parecia ser mais restrita. Entretanto, com o Tesouro, o Templo era o polo econômico dessa circulação, especialmente na Judeia, o que leva mais uma vez a falar de modo de produção tributário, pois é sabido que ele comporta uma poderosa intervenção do Estado, ao lado de um setor de propriedade e comércio privados. Por fim, o imposto da didracma, recebido dos judeus da diáspora, tornava o sistema econômico bastante peculiar, constituindo um sintoma da função social específica do Templo como aparelho ideológico que, ainda por cima, justificava o Estado.

Em suma, tratava-se de um modo de produção tributário, no entanto, além do fato de que as comunidades locais estavam estruturadas em um conjunto, observava-se, também, certos traços de uma sociedade feudal, em virtude da coexistência das grandes propriedades com as aldeias de propriedade e gestão coletivas. Além disso, como já se viu, no plano econômico, o poder central era fortemente marcado pelo elemento religioso, o Templo, o que dava de imediato, uma conotação particular ao sistema. A isso, acrescenta-se o fato de que a sociedade palestina era dominada por um império estrangeiro estruturado no modo de produção escravagista; mas, este último aspecto não é fundamental para determinar a relação de dependência, que se estabeleceu, sobretudo, pela extração de excedentes através de impostos. Enfim, há o detalhe de que o grande comércio internacional marcou mais profundamente a Galileia do que a Judeia.

\subsection{As Relações Sociais}

Tendo em vista a base econômica que foi descrita, a formação social da Palestina, na época de Jesus, apresentava um sistema social relativamente complexo, constituído por um sistema de classes sociais, tipo do modo de produção tributário. Além do Estado-classe e sua estratificação interna, a persistência de formas de relações tribais deve ser considerada. Mas, outros elementos também intervinham, juntamente com esses para a determinação de grupos sociais de múltiplas facetas: a origem étnica e os tabus religiosos. 0 sistema de classes sociais pode ser, assim observado.

A articulação das classes, em consonância com o sistema econômico, possuía uma estrutura duplamente triangular. No primeiro polo, encontrava-se a burguesia fundiária, composta pelos grandes proprietários de terras e rebanhos. Sua produção orientava-se principalmente para o mercado interno, constituindo-se no polo dinâmico para a criação de uma burguesia comercial. Esta, 
justamente, constituía o segundo polo: formada pelos grandes comerciantes, que dirigiam as atividades mercantes nacionais e internacionais, adquirindo uma progressiva autonomia à medida em que o tempo passava. Finalmente, havia o terceiro polo, formado pela oligarquia estatal e religiosa, composta por Herodes e sua família, por um lado e, pelos sacerdotes que formavam o alto-clero, administradores do Templo e de seu Tesouro, por outro. Embora os limites entre os três polos possam ser bem definidos estruturalmente, na realidade, eles eram limites móveis, pois, o setor das classes dominantes era formado por um pequeno número de famílias, nas quais se combinavam, frequentemente, os três polos que foram indicados.

Em torno de cada um desses polos, articulavam-se os setores explorados, que constituíam a condição de possibilidade dos primeiros: o proletariado agrícola e os escravos, o proletariado comercial e, por fim, o proletariado da corte e do Templo.

Separados deles e, em contradição com os interesses dos setores dominantes, situavam-se os setores intermediários, como a pequena burguesia camponesa (cultivo e criação), muito dependente da grande burguesia rural, tanto para a exploração da terra, como para a comercialização de produtos, a pequena burguesia artesanal e comercial e a pequena burguesia estatal e religiosa, formada pelos funcionários da burocracia real e do Templo, especialmente, o baixo clero.

Finalmente, deve-se mencionar um grupo social de relativa importância estrutural e significativa para a análise do nascimento do cristianismo: o grupo formado pelas massas marginalizadas do processo de produção, os desempregados, os mendigos, etc.

Jeremias, propõe uma classificação em termos de ricos, classe média e pobres. Apesar de se utilizar seus dados, prefere-se, porém, uma outra estruturação, que permita perceber mais tarde as contradições entre os diversos setores das classes, pois, por exemplo, o polo da burguesia era marcado por contradições entre o setor agrário e o setor comercial, bem como entre esse último e o setor estatal. Se o sistema fiscal revela a contradição entre a oligarquia estatal e religiosa e a burguesia agrária e comercial, a concorrência para atender às necessidades do mercado interno mostra as contradições entre o capital comercial e a burguesia agrária, bem como entre o capital comercial e a pequena burguesia artesanal.

No entanto, como a Palestina era uma formação social dependente, os interesses das diversas frações de classes não se diversificavam somente por razões internas, mas também e fundamentalmente, pela forma de integração ao centro hegemônico. Tanto a burguesia agrária, como a burguesia comercial estavam bem integradas no sistema comercial internacional dirigido por Roma. 0 mesmo não acontecia com a pequena burguesia, que se via empobrecida pelo sistema tributário e, deslocada do mercado interno pelo avanço das importações que, na época de Jesus, cobriam mais da metade dos produtos que abasteciam o mercado judeu.

A burguesia comercial era o setor que mais diretamente se beneficiava com a dominação romana, o que provocava uma união de interesses entre essa fração e as burguesias nacionais 
romanas. Já a incorporação da burguesia agrária à esfera da dominação romana não deixava de ter problemas. Quanto à classe tradicional, seus interesses nacionalistas eram atacados, o que provocava uma certa reserva em relação à Roma (reserva de ordem superestrutural) que se manifestava, sobretudo, pela oposição à fração da burguesia composta pela nobreza "real".

No polo dos dominados, a situação também era contraditória. 0 setor artesanal estruturado em torno do Templo, constituía uma fração, cujos interesses dificilmente poderiam ser unir ao do operário agrícola ou do escravo. Com um nível de capacidade e um nível de recursos bem superiores, esse proletariado urbano estava mais próximo dos interesses da pequena burguesia, do que dos interesses do proletariado rural.

Por fim, é digno de nota, o isolamento de uma massa bastante considerável da população: a massa constituída pelos setores marginalizados do processo de produção. Essa massa vivia fundamentalmente de esmolas e, em uma extrema miséria, incapaz de emigrar para o império ou se incorporar ao sistema de produção por falta do próprio sistema.

\subsection{O Sistema de Estratificação Social}

À superposição ao sistema de classes, pode-se encontrar um sistema de estratificação que revelava, a sobrevivência de elementos característicos do antigo modo de produção tribal. Esse sistema de estratificação tinha por eixo um elemento superestrutural: o critério de origem. Segundo a origem, os diversos graus da escala social estavam assim dispostos: I) membros de famílias de origem legítima; II) membros de famílias de origem ilegítima, atingidos por leve mácula; III) membros de famílias, cuja origem ilegítima era marcada por grave mácula.

Em companhia do clero, os primeiros constituíam o Israel puro, os membros dessas famílias tinham direito de se casarem com sacerdotes, vinculando-se, assim, à genealogia davídica, única capaz de garantir a pureza do sangue. A segunda camada continha uma série de subconjuntos, hierarquizados por ordem de pureza-impureza: descendentes ilegítimos de sacerdotes, trabalhadores de ofícios desprezíveis, escravos judeus, prosélitos, pagãos convertidos ao judaísmo, escravos pagãos libertos e escravos pagãos convertidos, mas, ainda, escravos. Os membros dessas diversas hierarquias sociais tinham direito de se casarem com levitas e judeus de origem legítima, o que constituía um mecanismo de ascensão social. Por fim, havia a terceira camada, composta pelos judeus portadores de grave mácula: os bastardos, os escravos do Templo, os filhos de pai desconhecido, os eunucos, os escravos pagãos, os samaritanos. Essa terceira camada não tinha nenhum direito, afora o direito ao desprezo.

Superpondo o sistema de estratificação ao sistema de classes, observa-se que a burguesia e a pequena burguesia, coincidiam (a não ser no caso dos ofícios desprezíveis) com a categoria dos judeus puros. Por outro lado, o proletariado, sobretudo, o agrícola, a massa de escravos e a massa 
marginalizada do processo de produção, correspondiam a um dos dois tipos de judeus impuros. Desse modo, embora residual, o sistema de estratificação exercia um papel social de primeira ordem, fortalecendo a estrutura de classes em termos de superestrutura. Graças a esse sistema, a estrutura de dominação escondia sua base econômica, manifestando-se como uma estrutura "natural", baseada na tradição. E, o caráter central do Templo reaparece, sob outro aspecto, como condensação da estrutura de dominação. Efetivamente, era o sacerdote que decidia quem era ou não era puro. Pela distinção entre puro e impuro, era ele quem estabelecia, não somente, um princípio de interpretação religiosa, mas também, um princípio de exclusão ou inclusão de ampla repercussão social.

Ademais, também havia tabus de origem religiosa. Aqueles que, de um ou outro modo, haviam transgredido a lei, eram considerados como pecadores: essa qualificação era geralmente transitória, mas, refletia uma punição de tipo religioso, legalista. Além disso, eram consideradas como impuras, as pessoas atingidas por certas doenças, especialmente, os doentes mentais, considerados como possuídos pelo demônio e os leprosos. Essa é a razão pela qual essas pessoas viviam à margem da vida social e cultural palestina.

\subsection{O Sistema Político}

No que tange ao sistema político, a estrutura de dominação, embora tenha suas raízes na base econômica, se condensa e recebe sua estruturação e solidez do Estado e do aparato estatal. No caso da formação social de Israel, na época de Jesus, a dualidade existente na base econômica e reproduzida ao nível do sistema social, também se reproduzia ao nível do sistema político: dualidade entre centros urbanos e zonas rurais, dualidade entre império e colônia.

O sistema de relações de autoridade e poder político era bem diferente, conforme tratava-se de centros urbanos ou comunidades rurais. No campo, as relações de autoridade permanente eram as relações familiares, da casa. De modo não permanente, um conselho de anciãos reunia-se, tanto para decidir sobre as questões comunitárias, como na condição de tribunal, em caso de litígio ou transgressão da Lei. Desse conselho, faziam parte os anciãos, isto é, os chefes de casas judias, escolhidos em função da pureza de seu sangue original e um sacerdote para as questões referentes à pureza e impureza. 0 chefe de família era o representante masculino mais idoso da linhagem, elemento que reproduzia a estrutura das antigas sociedades tribais.

Nos centros urbanos, centros por excelência da sociedade de classes, embora existissem conselhos como esses, eles estavam nas mãos daquilo que é chamada a nobreza laica, formada pela intelectualidade pequeno-burguesa - que na época começava a minar o poder da oligarquia tradicional. Ou seja, neste caso, fica-se diante de relações de classe e de concorrência política determinada por interesses de classe. 
Falando da composição do Sinédrio, Jeremias, indica que ele era composto por setenta e um membros: os sacerdotes à frente, representados pelo Sumo Sacerdote que era o presidente do Conselho, depois os escribas e os anciãos. Os anciãos eram os chefes de famílias patrícias de Israel, em geral, proprietários de terras e, em princípio, detentores de uma parcela importante do capital comercial. Esse grupo, sugeria a presença dos tradicionais chefes de casas. E, o outro grupo, o dos escribas, que mostrava que nos centros urbanos, o quadro da luta pelo poder era diferente do apresentado nas comunidades rurais. Com efeito, os escribas eram um grupo social em plena ascensão, desde à época dos macabeus, pertencendo em grande parte à pequena burguesia artesanal. Apoiandose não no poder do sangue, mas, no poder do saber, como mostra Jeremias, eles conquistavam um poder cada vez maior dentro de um organismo em que a leitura e a interpretação da Torá eram fundamentais. Lentamente, o Sinédrio caiu em suas mãos: de uma aliança entre a grande burguesia (sacerdotal-proprietária de terras-comercial) e a pequena burguesia intelectual-artesanal, sob a hegemonia da grande burguesia, passou para a hegemonia da pequena burguesia. Essa transição manifestou-se pelo lento deslocamento do partido dos saduceus e a crescente importância do partido dos fariseus.

Ao lado do Sinédrio, órgão de justiça do Estado, estava o Templo, órgão ideológico-religioso do Estado. Seu pessoal era composto de sacerdotes, assim estruturados, segundo Jeremias: o Sumo Sacerdote, que estava no centro do órgão, detentor do primado; os sacerdotes-chefes, entre os quais, o comandante do Templo; os chefes das 24 seções semanais e das seções diárias; os vigilantes (sete) e os tesoureiros (três); os sacerdotes (cerca de sete mil e duzentos) e, finalmente, os levitas, cantores e músicos, servos e guardiãs (cerca de nove mil e seiscentos).

Se, se insistesse nos números, seria para dar ao leitor uma ideia da importância desse aparato central, cuja importância econômica e social já se viu. Segundo os cálculos de Jeremias, o Templo agrupava uma população de dezoito mil funcionários, os quais, juntamente com mulheres e crianças, constituíam uma população de cinquenta a sessenta mil habitantes, para uma cidade como Jerusalém, cuja população global era de seiscentos mil habitantes. Isso significa que um décimo da população de Jerusalém estava ligado ao complexo institucional constituído pelo Templo. Flávio Josefo podia dizer com razão: "Em outros povos, outras considerações permitem determinar a nobreza; entre nós, ao contrário, é a condição de sacerdote que constitui a prova de uma origem ilustre”.

A monarquia era o terceiro componente do Estado judeu. Um Estado monárquico absolutamente dependente que a partir do ano VI d.C., com a deposição do tetrarca Arquelau, um dos três filhos de Herodes (o do massacre dos Inocentes) começou a perder a independência política conquistada por Judas Macabeu. Essa marionete do Estado romano manifestava sua fraqueza e, exercia sua dominação interna, por meio de uma política repressiva, tanto no terreno político, como no econômico. 0 Estado judeu, naquela época, nada tinha a invejar dos Estados mais despóticos da Ásia. 
Até que por fim, ele foi deposto pelos romanos, sob pressão de instâncias judias e deportado para a Gália.

O aparato central do Estado era estritamente judeu, modelando-se bastante claramente pelo modo de produção tributário. Entretanto, a exemplo do nível econômico, no qual havia o domínio de uma potência estrangeira estruturada, segundo outro modo de produção, também, aqui, encontra-se algo semelhante, na medida em que o Estado judeu era controlado pelo Estado romano. A história da gênese dessa dominação é descrita desta forma: não é necessário, alongar-se sobre ela. Da mesma forma, não se deterá na análise das causas de uma tal dependência, pois isso, acarretaria uma caminhada muito além. Pretende-se destacar, somente, algumas características observadas pelos autores consultados. Como assinala Jeremias, o Estado judeu possuía um dinamismo próprio, controlado pelo Estado romano.

Depois do ano VI d. C., Roma nomeou um procurador encarregado diretamente da Judeia e da Samaria. A Galileia, por seu turno, pertencia à província romana da Síria e dependia do legado romano desse território. Pelo sistema de procuradores, Roma assegurava o domínio de Israel. Esse sistema funcionava por meio de um duplo mecanismo de controle: direito de nomear e depor os Sumos Sacerdotes e de referendar a dependência dos anciãos e da nobreza laica. Assim, a aristocracia fundiária não se sentia inteiramente tranquila na posse de seus bens, pois, toda a terra pertencia teoricamente ao Estado. Muitas vezes, as terras haviam sido submetidas a dízimos ou expropriadas, arbitrariamente, por Herodes e outros chefes do Estado, desde os tempos em que os Pitlomeus haviam estabelecido os grandes domínios, confiando-os a donos individuais, tendo em vista uma explicação direta ou indireta, mas, submetendo o proprietário a uma sempre possível destituição arbitrária. Diante dessa permanente ameaça, deliberadamente manifestada pelas autoridades romanas, a classe dos proprietários de terras, como informa Jeremias, desenvolveu ao mesmo tempo, traços de servilismo, em relação às autoridades e uma impiedosa exploração de seus próprios concidadãos. Em troca, essa atitude era bem recompensada por Roma, pois, era entre os anciãos do Sinédrio e os outros anciãos das famílias que o procurador escolhia comumente os funcionários para a cobrança dos impostos, os decaprotes, que respondiam de seu próprio bolso pelo seu exato pagamento. Até o momento, limitou-se a análise do aparato estatal. Mas, o sistema político não se reduz a esse aparato. Pode-se considera-lo como o palco onde atuam os diversos protagonistas sociais. No caso da formação social da Palestina, na época de Jesus, tais protagonistas são as diversas classes e frações de classe. A análise dessa prática política de classes, pode possibilitar uma visão mais completa do sistema social e político da Palestina. Para concluir, deve-se recordar que o Templo, cujas funções econômicas já foram descritas, também era o centro do poder político e o próprio lugar de funcionamento do Estado. 


\subsection{Estrutura de Classes, Poder Político e Correntes Ideológicas}

Assim, passa-se agora, à análise da estrutura de classes, poder político e correntes ideológicas na Palestina, no tempo de Jesus.

a) Os Saduceus.

A aristocracia sacerdotal e a grande burguesia fundiária, encontravam-se organizadas há muito tempo, em torno do partido dos saduceus, nome oriundo provavelmente da época de Salomão, cujo Sumo Sacerdote chamava-se Sadoc. Estreitamente ligado ao Templo e às tradições, esse partido fora hegemônico até a época dos macabeus. Posteriormente, com o apogeu da atividade comercial e a ascensão da pequena burguesia, ele havia perdido sua hegemonia, limitando-se, na época de Jesus, ao controle do poder judiciário e da autoridade governamental.

Gripo social em decadência, apegava-se à posição social, defendendo tenazmente a tradição e, rejeitando os escribas e as novas concepções da pequena burguesia intelectual, que haviam assimilado os elementos culturais da Grécia e de Roma. A disputa, à propósito da ressureição dos mortos, negada pelos saduceus e afirmada pelos fariseus é um exemplo, ao nível ideológico, dos conflitos práticos entre essas duas classes sociais. Incapazes de impor sua hegemonia ao povo, mantinham uma atitude dura e intransigente, em relação a ele, gozando plenamente das vantagens de sua posição social. Ao nível ideológico, o que distinguia os saduceus era a negação da tradição de Israel, no que se referia às esperanças messiânicas. Tal silêncio devido, sem dúvida à aliança dessa classe com o Império romano, explica-se também pela rejeição à mudança expressa no messianismo, mudança que faria desaparecer a sua dominação como classe.

b) Os Fariseus.

A burguesia comercial, a pequena burguesia camponesa e a pequena burguesia artesanal, isto é, a imensa maioria da população de Israel, eram controladas pelo grupo dos fariseus. Verdadeiro grupo hegemônico no sistema político de Israel, os fariseus eram conhecidos desde a época de João Hircano. Inicialmente, aliados com a aristocracia sacerdotal e a burguesia agrícola, os "separados" ou "separatistas", começaram a se afastar deles para dirigir o povo. A partir da conquista da Palestina por Pompeo e, durante a conquista herodiana, bem como sob o governo dos procuradores, eles constituíram o partido popular de resistência passiva.

Diferentemente dos saduceus, os fariseus constituíam um grupo fortemente estruturado em comunidades de natureza laica, se bem que englobando a maioria do baixo clero, que estava em contradição com os interesses da aristocracia sacerdotal dos saduceus. Sem seu qualificativo de 
"separados" expressa bem a sua consciência de classe pequeno-burguesa: por um lado, "separados" dos chefes da aristocracia; por outro, "separados" dos am ha-ares ou "povo da terra", os escravos e a massa marginalizada do processo de produção aqueles que não conheciam "seriamente" a Lei e careciam de instrução e cultura.

Religiosamente, os fariseus caracterizavam-se pelo rigoroso cumprimento da Torá, em todos os domínios e todas as situações da vida cotidiana. Seu zelo religioso era não somente conservador (manutenção da Lei), mas, também, uma expressão da nova classe hegemônica, criadora de novas tradições pela interpretação da Lei, naquele momento histórico. Esse movimento de criação, de nova tradição, expressou-se ao nível institucional pela ruptura com a instituição tradicional, expressão da antiga hegemonia da aristocracia e da burguesia agrária: o Templo. Diante do Templo, os fariseus colocaram a Sinagoga. 0 culto e os sacrifícios do Templo, fonte de renda e de poder da aristocracia sacerdotal, opunham-se à Sinagoga, com seu serviço religioso de leitura e interpretação dos textos bíblicos e de confissão e oração. Assim, diante do Templo, a Sinagoga constituía a expressão farisaica de uma nova consciência religiosa que, ao mesmo tempo, era também uma nova consciência política.

Diferentemente da aristocracia e da grande burguesia agrária, que não necessitavam de ideias messiânicas, nem de crenças em outra vida, a pequena burguesia apresentava uma forte expectativa messiânica, orientada para esse mundo. Eles acreditavam no Messias, mas isso não os lançava em sonhos visionários, sem relação com as possibilidades práticas.

Eles acreditavam de todo coração no Messias, tendo dele uma concepção, ao mesmo tempo, política e espiritual. Para eles e seus discípulos, não havia qualquer dúvida sobre sua vinda. Mas, não deixavam de afirmar que seu papel era o de precipitar o fim e, não se entregavam a um fazedor de milagres que poderia conduzir a nação à catástrofe.

Um messianismo prudente e moderado e a crença na ressureição e na predestinação eram os valores que faziam da pequena burguesia farisaica, uma classe extremamente ativa no plano social e econômico. Em sua análise do antigo judaísmo, Max Weber mostra claramente o papel da ética farisaica no desenvolvimento econômico do povo judeu, como um papel semelhante ao desempenhado pela ética calvinista do capitalismo. Para tal ética, o trabalho permanente e consciente, a seriedade e a aplicação às tarefas do presente, constituíam o modo de preparar a vinda do Messias.

Opondo-se ao ideal saduceu de um Estado-Templo Nacional e particularista que, esperava ser libertado das garras pagãs, purificado e restaurado, os fariseus procuravam uma aproximação com o mundo pagão, sobretudo, com o helenismo. Essa posição mais liberal foi o que determinou suas relações com o império romano. A dominação romana era lida pelo farisaísmo em termos religiosos como castigo ao pecado de Israel e, portanto, como motivo de purificação e conversão do povo. Assim, reinterpretada ao nível ideológico e, em função de seu projeto de hegemonia social, a dominação romana, concretamente, devia ser encarada com realismo. 
$\mathrm{Na}$ época de Jesus, relacionados com esse movimento fariseu, haviam três outros grupos de diversa importância, no interior da pequena burguesia judia. É interessante situa-los no mosaico, porque a prática de Jesus esteve em estreita relação com eles.

c) Os Escribas.

É um grupo que aparece frequentemente nos Evangelhos. Ao lado dos fariseus e, de tal forma ligados à eles, que é quase impossível distingui-los, os escribas constituíam a categoria social mais importante no seio da nova classe hegemônica. Segundo Jeremias, "o saber é o único fator a representar o poder dos escribas". Foi assim que eles conquistaram lentamente os postos chaves da instância superestrutural, para os quais haviam sido formados intelectualmente: direito, administração, educação. Graças a esse fato, os escribas desempenharam um papel estratégico na conquista do poder pela nova classe. Grupo culto da pequena burguesia, eles ganharam poder no Sinédrio e na Sinagoga. No Sinédrio, como corte de justiça, eram determinantes o conhecimento e a exegese dos textos tradicionais. Na Sinagoga, eles se apresentavam como criadores de tradição pela releitura dos textos antigos, escondendo ao povo, por meio de esoterismo, os mecanismos de sua produção ideológica. Não se deve explicar publicamente as leis sobre o incesto diante de três ouvintes, nem a história da criação do mundo, diante de dois, nem a visão do carro diante de um só ouvinte, a menos que ele seja sábio e julgue com bom senso. Para aquele que considerar quatro coisas, seria melhor nem ter vindo ao mundo, a saber: primeiro, o que está no alto; segundo, o que está embaixo; terceiro, o que havia antes; quarto, o que haverá depois. 0 segredo da divindade, o da criação e o do futuro caracterizavam a tradição esotérica típica dos escribas. A posse dessa ciência legitimava o seu ensinamento para o povo, pois, tornava-os herdeiros imediatos e sucessores dos profetas. A que se assemelham o profeta e o escriba, a dois enviados de um único e mesmo rei, respondia o Talmud da Palestina.

d) Os Essênios.

Grupo saído do partido dos fariseus, sua origem remonta à "comunidade da Aliança", da época dos macabeus. Sua organização comunitária rígida caracterizava-se pelo sacerdócio e a hierarquia, bem como por um rigoroso legalismo, uma espiritualidade apocalíptica e a pretensão de representar o verdadeiro povo de Israel. Em muitos pontos semelhantes aos fariseus, eles constituíam um grupo fariseu radicalizado no domínio ideológico-religioso. Entretanto, distinguiam-se dos fariseus pela ruptura radical com o judaísmo oficial, pelo apego a certas tradições sacerdotais e, por seu isolamento, próximo do sectarismo. Eles deixaram Jerusalém estabelecendo-se nas regiões de grutas para lá viverem o seu ideal monástico. 
As ordens religiosas cristãs herdaram muito de sua organização: condições de admissão à comunidade estritamente determinadas, tempo de noviciado; estrutura hierárquica de governo, com funções bem distintas; severa disciplina; meticuloso ritual de purificação; ceias sagradas comunitárias, etc. Tudo isso formava o ambiente em que viviam aqueles homens, cuja existência era interpretada de mil modos. No que se refere à sua posição política, os autores são unânimes em destacar o seu caráter apolítico. Considerados como modelos de piedade, os essênios tinham uma participação particularmente nula na vida política, até as guerras de libertação contra os romanos, nas quais se uniram ativamente à luta do povo. No tempo de Filon e Josefo, os essênios eram cerca de quatro mil. Eles viviam somente na Palestina, morando em aldeias e alguns nas cidades. Na época de Plínio, já podiam ser encontrados perto do Mar Morto. Em suas aldeias, viviam comunitariamente, como já foi mostrado, dividindo igualitariamente os seus bens. Os produtos do trabalho eram divididos igualmente entre todos, os alimentos e, também, as roupas eram de uso comum. 0 comércio era proibido entre eles, como também o derramamento de sangue, mesmo o das vítimas do Templo.

Movimento formado de camponeses, os essênios realizavam seu trabalho recusando-se à fabricação de armas. Em resumo, sua lei fundamental era a de viver em paz, do produto de seu trabalho e evitar tudo o que pudesse fazer mal a outrem. Seu sinal exterior característico era a túnica branca, dada a todo neófito que ingressava na comunidade. Geralmente, os essênios não se casavam, a fim de se preservarem da impureza e em paz adorarem o Senhor.

Analisando os essênios, pode-se sintetizar as características desse grupo de "monges" ascetas: pode-se representar o escenismo como um grande sonho, ao mesmo tempo, humanitário e nacional. Ele concretiza de modo marcante o socialismo moral dos profetas: foi a primeira utopia socialista feita realidade (com) a igualdade entre os membros do grupo, a comunidade de bens, a proibição de derramar sangue, mesmo sob a forma de sacrifícios religiosos e, sobretudo, a obrigação de trabalhar com as próprias mãos.

e) Os Zelotas.

Os zelotas se agrupavam dentro do partido dos fariseus. Flávio Josefo e o Novo Testamento falam desses grupos. Em At. 5, 37, pode-se ler: "depois dele na época do recenciamento apareceu Judas, o Galileu, que sublevou muita gente em sua sequela. Pereceu ele, também, e os que se haviam aliado a ele foram dispersos. Esse texto leva ao ano VI, quando Quirino, legado da Síria, realizou um recenseamento na Palestina. Então, muitos judeus lutaram de armas nas mãos, sob a direção de Judas, o Galileu. 0 recenseamento visava conhecer a população judia, sobretudo, seus bens, a fim de poder fixar o imposto devido à Roma. Para os judeus, esse censo constituía o sinal mais evidente de sua escravidão, em relação à Roma, dando aos publicanos a possibilidade de extorqui-los, ainda mais. Daí, 
a sangrenta oposição ao recenseamento. Desde então, a palavra greco-latina "censo" tornou-se sinônimo de castigo em hebraico.

0 resultado desse recenseamento foi a união dos grupos nacionalistas mais fortes, no partido dos zelotas ou fanáticos. 0 seu protesto era evidente: era uma indignidade que os judeus fossem escravizados em carne e osso. 0 Rei de Israel era o próprio Deus e não o Imperador Romano, que não passava de um idólatra. Os historiadores judeus, em geral, fariseus como Flávio Josefo, ou simplesmente dos fariseus, falam dos zelotas como de um grupo extremista, sem uma clara visão política. E, isso, quando não chegam a falar de bandidos e salteadores. Contudo, na realidade, o partido zelota era profundamente nacionalista, saído do seio do farisaísmo, com a mesma origem de classe, mas com uma concepção estratégica diferente da oposição à Roma. 0 messianismo religioso-político e o ideal de Estado teocrático dos fariseus constituíam para os Zelotas, a razão de sua luta, uma luta mortal contra a dominação romana. Em consequência, tiveram que enfrentar a dura repressão romana, que via neles a ameaça mais séria para a ordem interna de sua dominação, em virtude de seu enraizamento popular. 0 testemunho de tal repressão pode ser encontrado em Lucas 13, 1: "neste momento vieram algumas pessoas que lhe contaram o que acontecera com os galileus, cujo sangue Pilatos havia misturado com o das suas vítimas".

A luta dos zelotas não se dirigia unicamente contra Roma, mas também, em grau bastante considerável, contra o reino de Edom, isto é, contra o governo de Herodes, o hedomita. Sua estratégia armada criou sérias contradições entre os zelotas e a pequena burguesia intelectualizada, o que fez com que o movimento zelota tivesse que lutar não só contra as armas de Roma e de Herodes, mas também, contra a hegemonia dos fariseus e sua fração escriba. Ao que parece, o recrutamento dos combatentes se efetuava na classe dos pequenos camponeses, que sofriam mais particularmente a dupla colonização colonial e local. Antes da época de Jesus, a repressão romana contra movimentos semelhantes havia sido especialmente brutal. Varo, legado romano da Síria, havia feito crucificar duas mil pessoas.

Animados pela ideologia política-religiosa de que se falou, os zelotas chegaram ao poder no ano de sessenta e oito, depois de matarem o Sumo Sacerdote, em exercício. Eles, então, instalaram um novo Sumo Sacerdote, escolhido em uma das famílias tradicionais. Quando os romanos reagiram contra seu poder, em setenta, eles defenderam o Templo como sede de todo o simbolismo religioso, até o último homem. Foi isso que provocou a queda de Jerusalém. 0 movimento zelota por conseguinte poderia ser "reformista", desde que esse termo não receba a conotação de elementos contemporâneos, ou ainda, "retrógrado", pois, desejava restabelecer uma situação passada, restaurando o Estado teocrático na linha de um messianismo davídico. Às vezes, apresentado como um movimento de guerrilhas, destinado a estabelecer uma sociedade em que seria abolida a divisão de classes, o movimento zelota não tinha esse caráter. Os pequenos camponeses eram levados à luta armada, em 
virtude de sua situação desesperada e, não em função de uma ideologia que representasse os seus interesses objetivos.

\section{f) Os Herodianos.}

À margem dos dois grandes partidos, saduceus e fariseus, deve-se mencionar o grupo formado pelos funcionários da corte de Herodes. Ainda que eles não formassem propriamente um partido político, são mencionados como um importante grupo no Evangelho. Politicamente, os herodianos procuravam o apoio dos fariseus já que estes dominavam o povo. Pode parecer bem estranha essa combinação entre os romanófilos e helenizantes da corte e os puros de Israel. Todavia, não se pode esquecer que, diante de situações de agudos conflitos, realizam-se as alianças mais estranhas. A época de Jesus testemunhou uma dessas situações e face a Jesus, também se produziram estranhas alianças. Logicamente, os herodianos eram desprezados por todos os judeus, já que concretizavam o vínculo de dependência de Israel, em relação à Roma. 0 desprezo de Jesus por eles é notório. E, nisso, ele não era uma exceção.

Em resumo, ao nível dos protagonistas sociais, encontra-se, na formação social de Israel, no tempo de Jesus, diante de uma série de partidos que em suas relações e contradições, configuravam o campo das forças religiosas e políticas. Trata-se, de uma estrutura política que expressava a estrutura de classes, dando-lhe existência e solidez. Finalmente, convém ressaltar o sistema ideológico e as funções sociais da religião.

Ao analisar os subsistemas produzidos por cada protagonista social coletivo, já se apresentou diversos elementos constitutivos do sistema ideológico. Resta agora, dar uma visão de conjunto. Evidentemente, é difícil expressar em algumas linhas, a essência da ideologia sócio religiosa de Israel, no século I. Em suma, pode-se dizer que a crença em um Deus único, isto é, o monoteísmo do povo de Israel, fruto de uma longa evolução, constituía a base de todo o sistema ideológico. Deus conduziu seu povo e Israel devia ser-lhe fiel. Isso se inscrevia em um pensamento fundamental, situado em Deus, a origem do mundo e do homem e, expressando a relação entre os dois, sobretudo, pela queda e pela introdução do mal no mundo. A isso se acrescia uma interpretação da origem do povo de Israel ligada aos seus ancestrais. Abraão, Isaac e Jacó. A história de Israel apresentava-se como a formação de um povo, que era o povo de Iahweh, o Deus tornado único.

A conquista de Canaã era interpretada como o cumprimento da Promessa e como a continuidade da bênção de Deus a seu povo para o futuro, com a condição de que ele obedecesse à Lei. De sacerdotes tribais, Israel havia passado à monarquia, transformada na literatura profética em um dos símbolos do mal, da exploração e, daquilo que se poderia chamar, em linguagem moderna, o aparecimento de uma sociedade de classes. Daí, a reação dos profetas, manifestando uma esperança 
messiânica, a ideia de uma nova aliança entre Deus e seu povo, a ideia de uma nova Jerusalém, implicando um destino coletivo do povo, mas, no próprio seio da história.

O sistema ideológico era dominado por dois grupos de especialistas, que monopolizavam quase totalmente, o campo das representações, costumes e comprometimentos da sociedade israelita: os sacerdotes, através do Templo e os escribas, por meio do ensino nas Sinagogas. É evidente que o sistema ideológico não se esgotava nesses dois polos, mas, eram eles os dominantes. Segundo a prática ideológica dos escribas, caracterizava-se pelo fato de partir de três tipos de textos, herdados da tradição: os textos da Sabedoria, os textos do Targum e os textos apocalípticos.

Entre os textos da Sabedoria, primava o de Jó: “A problemática individual assume o primeiro plano, os textos se interrogam sobre o destino pessoal, sobre a infelicidade da condição de que, precisamente, permaneceu fiel à Lei de Iahweh". Entretanto, como o Livro de Jó não fornecia uma resposta, continuava-se a esperar para além da angústia, com a certeza de que era a morte que esperava a todos. Começou-se, então, a elaborar critérios de conduta individual, estabelecidos a partir do conhecimento da natureza e da sociedade. O livro dos Provérbios e Eclesiastes forneciam o quadro para essa elaboração da pequena burguesia angustiada por sua sorte individual.

Unida a essa consciência, aparecia a leitura dos textos apocalípticos que, pressupondo a existência de uma analogia geral entre a "ação salvadora de Deus e a ordem da natureza", convertia a angústia em esperança, uma esperança que se apoiava na dominação da natureza e no conhecimento da história.

Já os textos do Targum, surgidos das práticas das sinagogas, revelam a releitura dos textos antigos que se fazia sob a égide dessa nova consciência orientada, por um lado, para esse mundo e por outro, para o futuro messiânico. Essas duas características, que poderiam parecer contraditórias, na verdade, não o são, na medida em que, o ideal messiânico adquiria características intramundanas.

Ao lado desse polo "escriba" encontrava-se a linguagem ritual do culto monopolizada pela fração sacerdotal, bem como o complexo código normativo construído a partir do eixo puro-impuro. Não se deterá aqui, na análise desse código. Devido ao objetivo do trabalho, é o tema messiânico que se quer desenvolver. A literatura apocalíptica dava uma grande importância ao messianismo. Produzida pela pequena burguesia farisaica e pelo esoterismo escriba, ela seria modificada por cada grupo social, segundo suas condições materiais de existência, mas, fundamentalmente manteria os traços comuns ligados à situação de dominação.

Foi por volta de 200 a.C. que a literatura apocalíptica fez seu ingresso na ideologia religiosa de Israel. De origem persa, ela tinha por característica, estabelecer um vínculo entre a ordem da natureza e a ordem da história, desenvolvendo a ideia de uma salvação individual, bem como de um juízo final, da ressureição e do restabelecimento de toda a ordem da criação. Essa literatura foi influenciada por Zaratustra, que desenvolveu suas ideias religiosas na Pérsia, a partir de grupos sociais urbanos. No judaísmo, essa influência manifestou-se, sobretudo, com os macabeus. 
Da literatura apocalíptica nasceram dois tipos de escatologia diferentes: uma, milenarista e, outra, mais simples e próxima da velha ideia do reino. Os elementos fundamentais dessas concepções eram os seguintes: 1) a vinda de um Messias, precedido pelo profeta Elias; 2) sua chegada provocaria a organização dos maus, em torno de um chefe; 3) esse exército do mal seria finalmente vencido; 4) a inauguração do reino messiânico, com a purificação de Jerusalém e a reunião do povo; depois, a ressureição dos justos de Israel e a instauração do Reino de Deus; 5) o juízo final, com a instauração de uma divisão entre os homens: uns participando da glória de Deus e outros indo para o inferno.

Um esquema profético dominante, característica do sistema ideológico, encontrava-se subjacente a essa temática messiânica. Tal esquema profético caracterizava-se pela oposição altobaixo céu-terra, daí decorrendo os movimentos ascendente-descendente. O Messias viria do alto como a chuva na primavera. E, sua missão seria levar consigo para a glória de Deus, situada no alto, o povo redimido. A fumaça do sacrifício e a oração, elevando-se, já simbolizavam, em primícias, o futuro reino messiânico. 0 espaço era dividido com certos pontos geográficos, sendo revestidos de importância simbólica. A montanha, por exemplo, lugar mais alto da terra, o mais perto do mundo "do alto", era o lugar privilegiado de união entre o povo e seu Deus, como se poderia depreender da revelação a Moisés e da revelação a Elias (e a transfiguração de Jesus, sua morte e ascensão). 0 fundo do mar, lugar mais profundo da terra, o mais perto do espaço simbólico "de baixo", era a região da morte por oposição à anterior, que era a região da vida. Por fim, o deserto era um lugar ambíguo, pois, se tratava de local não habitado, lugar de prova e tentação, já que a ele tinham acesso tanto as potências do mal, como as potências do bem. Tratava-se do espaço em que se tomava a decisão pró ou contra Deus, daí sua importância na vida do Messias.

Esse eixo de inclusão-exclusão era fortalecido por elementos das culturas próximas de Israel. A ele iria juntar-se o esquema interior-exterior que, usado com o esquema alto-baixo, formaria um eixo central, produção ideológica da época: o puro-impuro. 0 puro, estava geralmente associado à interioridade e ao sublime, ao passo que, o impuro, ligava-se ao exterior e ao baixo. A carne, o sangue, o sexo (como carne e sangue) e os ofícios relacionados com o sangue, a carne e a terra seriam considerados como impuros. Daí a importância do nascimento virginal do Messias, que, como enviado sagrado, proveniente do alto e do interior, não poderia ser maculado pela carne e o sangue. Em torno disso, se estruturava todo o sistema de proibições da Lei.

O esquema profético inclusão-exclusão, pressupondo os eixos anteriores, desembocaria no eixo judeu-pagão. 0 polo judeu representava o polo da pureza, da consagração à piedade e do caráter de povo eleito pelo alto, chamado a ser poderoso, na medida em que encontra esse destino. 0 polo pagão, era o oposto em todos os termos: impuro, carnal e possuído pelos poderes malignos. Assim, esquemas secundários facilmente qualificariam essa oposição em termos de luz-trevas, verdadementira, visão-cegueira, centro-periferia. 
Nessa trama de complexos eixos simbólicos, teria-se a prática ideológica dos diversos grupos sociais, inclusive, a prática de Jesus e dos grupos cristãos. Em que medida a prática discursiva de Jesus rompeu com a problemática dominante, articulando esses diversos eixos de modo diferente, constituindo um estudo que ainda está por se realizar em sua totalidade, mas cuja importância, tornase cada dia mais clara?

Com esses elementos, que se acabou de enumerar suscintamente, a consciência de Israel teceu, ao longo dos anos, a esperança messiânica, na qual os homens daquela formação social viviam sua relação com as condições reais de existência, condições de dominação e exploração. Já se destacou que a grande burguesia, na medida em que gozava do poder da dominação romana, desprezava a escatologia. Mas, para as outras classes, ao contrário, a ideia messiânica tinha um forte sentido. Enquanto os essênios viviam essa ideia à margem da sociedade, levando até as últimas consequências o esquema profético, para os fariseus e os escribas, privados de força política, à espera do Messias era vivida no pietismo, no legalismo e, numa consagração ao trabalho, que era a expressão de uma profunda angústia. Por fim, os zelotas traduziam a expectativa em uma prática guerreira de libertação, tentando forçar a realização do reino, por meio da espada.

Concluindo, a formação social de Israel, na época de Jesus, era uma complexa estrutura, resultante da articulação entre diversas instâncias. A articulação entre os sistemas econômico e político tinha o seu ponto central no Estado-Templo, grande expropriador da força de trabalho urbana, por meio do sistema fiscal sobre o artesanato e o comércio e, monopolizador da mais-valia, proveniente da massa formada pelas comunidades de produção agrícola. 0 sistema político se articulava com o sistema ideológico-religioso, no mesmo Estado-Templo, por um lado e, na atividade das Sinagogas, por outro, monopolizada pelo partido fariseu, verdadeiro detentor da hegemonia político-religioso-ideológica. 0 Templo era o lugar da presença divina, o que dava uma garantia suprema ao conjunto da sociedade.

A articulação do sistema econômico com o sistema ideológico-religioso realizava-se pela correspondência entre a posição dos diversos protagonistas sociais no processo de produção e na estrutura social e a sua consciência messiânico-nacionalista.

Finalmente, a articulação da colônia judia com o centro romano, fazia-se em diferentes níveis: ao nível econômico, através da política fiscal; ao nível político, pela aliança entre a aristocracia sacerdotal e a nobreza leiga judia com o poder militar romano; ao nível militar, através da ocupação e a repressão exercidas conjuntamente pelas legiões romanas e as forças militares herodianas; enfim, ao nível ideológico, através do duplo movimento de penetração-aculturação que caracterizava as camadas dirigentes e certos setores da pequena burguesia comercial.

Foi nesse contexto, que surgiram a pessoa e a prática de Jesus de Nazaré, um carpinteiro, filho de carpinteiro. Sua produção religiosa e sua prática profética iriam se desenvolver em continuidade ou 
em ruptura com essas condições sociais concretas, mas sempre em relação com elas (HOUTART, 1982).

\section{A PREGAC̣̃̃O DA “BOA NOVA” POR CRISTO, NOS TERRITÓRIOS DA PALESTINA, DO SÉCULO I}

\subsection{Os Territórios Percorridos por Cristo, na Palestina, segundo Flávio Josefo, historiador judeu do século I}

A Galileia, que se divide em duas partes denominadas Alta Galileia e Baixa Galileia, estava compreendida entre a Fenícia e a Síria; a ocidente confinava com o território de Ptolemaida e com o Carmelo, o monte que outrora fora dos galileus e agora pertencia aos de Tiro. Na parte meridional, confinava com a Samaria e com Citópolis, até o curso do Jordão. Para oriente, estava delimitada pelos territórios de Hipos, Gadara e Gaulanítide, onde estão, também, os confins do reino de Agripa. A parte setentrional, confinava com Tiro e com o território dos Tírios. A Galileia chamada Baixa, se estendia em longitude de Tiberíades, até Zabulon, perto da Ptolemaida, sobre a costa. Em latitude, se estendia de uma aldeia citada na grande planície, de nome Xalot, até Bersabe, onde também tinha início a Alta Galileia, que chegava até a aldeia de Baca; esta, marcava o confim como território dos Tírios. A Alta Galileia se estendia em longitude do povoado de Tela, perto do Jordão, até Merot (35-40).

Mesmo tendo esta modesta extensão e, estando circundadas por tantos povos estrangeiros, as duas Galileias sempre se defenderam de toda invasão inimiga; com efeito, os galileus foram belicosos desde pequenos e sempre foram numerosos e, como os habitantes, jamais conheceram a covardia. Assim, a região jamais conheceu a despopulação, porque era toda fértil e rica de pastagens e de árvores de todo tipo, de modo que tal fertilidade seduziu mesmo a quem era menos propenso ao trabalho dos campos. Por isso, era cultivada pelos habitantes e, não existia ângulo que não fosse trabalhado, antes, existindo ali, também, muitas cidades e por todo lugar, um grande número de aldeias densamente povoadas, por causa do bem-estar, de modo que a menor dessas, tinha mais de 15 mil habitantes (41-43). 
MAPA 2 - A PALESTINA NO TEMPO DE JESUS

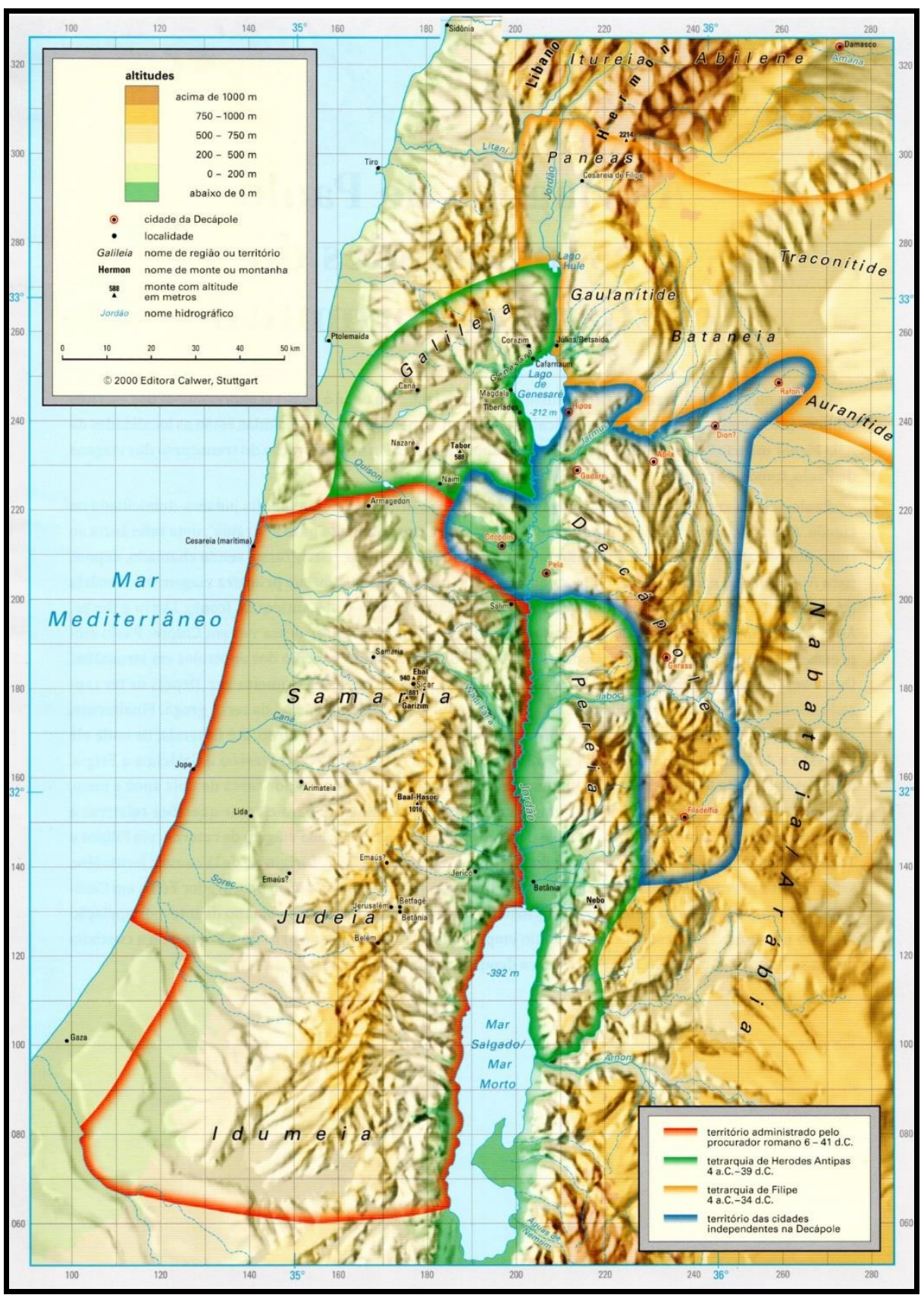

Fonte: Zwickel, p. 36, 2010.

Finalmente, mesmo que fosse menos extensa que a Pereia, a Galileia a superava por produtividade; esta, de fato, estava toda cultivada e produzia continuamente frutos, enquanto a Pereia, certamente muito grande, era na maior parte, deserta e penhascosa, muito selvagem para produzir frutos comestíveis (todavia, as partes menos ásperas dessa, produziam frutos de toda espécie e as planícies eram ricas de árvores variadas, entre as quais se cultivavam, principalmente, a oliveira, a videira e as palmeiras), banhada por torrentes que desciam dos montes e, também, bastante por fontes perenes, quando aquelas secavam pelo calor intenso. Estendia-se em latitude de Maqueronte à Pela e, em longitude, de Filadélfia até o Jordão. Sua parte setentrional confinava com Pela - que nomeamos

PONTES, B. M. S. Movimento social judeu que resultou no cristianismo primitivo: Da pregação da "boa nova"... 
antes - e, sua parte ocidental, com o Jordão; ao sul, seu confim era marcado pelo território dos moabitas; para oriente, confinava com Arábia e Sibonítida.

A região da Samaria, encontrava-se entre a Galileia e a Judeia; essa, de fato, começava da aldeia chamada Ginea, citada na grande planície e terminava na toparquia de Acrabatana; sua natureza era semelhante à da Judeia. Com efeito, ambas apresentavam quer montanhas, quer planícies, adaptadas ao cultivo e férteis, ricas de árvores e plenas de frutos selvagens e comestíveis, já que em nenhum lugar, essas eram desérticas por natureza, mas, eram quase sempre, banhadas pela chuva. Ali, todo curso de água era particularmente doce e, pela abundância de boas pastagens, os animais produziam mais leite do que em outros lugares. A prova principal da produtividade e da opulência da terra era que ambas estavam densamente povoadas (48-50).

No confim da Samaria e da Judeia, estava a aldeia Anuat, chamada também Borceos; esta, marcava o limite da Judeia, ao norte, enquanto a parte meridional dessa - na sua máxima extensão tocava uma aldeia nos confins da Arábia, chamada Jardan, pelos judeus do lugar. Em longitude, a Judeia se estendia do Rio Jordão, até Jope. Precisamente no centro dela, estava situada a cidade de Jerusalém e, por isso, alguns - com justiça - a chamavam a cidade umbigo da região. A Judeia, ademais, não estava privada dos benefícios do Mar, porque descia para a costa desde um planalto que chegava até a Ptolemaida. Dividia-se em 11 distritos, dos quais o primeiro e principal era Jerusalém, que dominava todo o território como a cabeça, o corpo; os outros depois desse, delimitam as toparquias: o segundo era Gofna e, logo vinha Acrabata, depois Tamna, Lida, Emaus, Pela, Idumeia, Engadi, Heródion e Jericó; depois destes, devemos citar Jâmnia e Jope, que administravam as regiões circunvizinhas e, depois, as regiões de Gamala, Gaulanítide, Bataneia e Traconítide, que faziam, também, parte do reino de Agripa. Este começava do Monte Líbano e das fontes do Jordão e, se estendia em latitude, até o lago de Tiberíades e, em longitude, indo de uma aldeia chamada Arfa, até Júlia; habitava-o uma população mista de judeus e de sírios (51-57).

O lago Galileia - cujas margens do noroeste testemunharam a atividade principal de Jesus, na sua região -, mas também, do Jordão: o lago de Genesaré, que tomou o nome do território adjacente, tinha uma largura de 40 estádios ( 1 estádio $=185$ metros) e, um comprimento de 140 metros. Sua água era doce e muito boa de beber. No lago, viviam algumas espécies de peixes diferentes, tanto em forma, como em sabor, daqueles de qualquer outro lugar. No seu centro, corria o Jordão, que parecia iniciar do Panion. Na realidade, ao Panion chegava com um percurso subterrâneo, nascendo de uma bacia de nome Fiala. Esta, se encontrava a 120 estádios de Cesareia (de Felipe), à direita e, não longe, da estrada que conduzia à Traconítide. A bacia tomvaa o nome de Fiala de sua forma circular, tratandose de um pequeno lago redondo e a água o enchia até a beira, sem jamais abaixar ou transbordar. A beleza natural do Panion foi aprimorada pela liberdade régia e embelezada às expensas de Agripa. Ora o Jordão, começando deste lugar a correr em superfície, intersecava o pântano e os brejos do lago Semeconita e, depois de um percurso de outros 120 estádios, ultrapassava a cidade de Júlia, fluindo no 
meio do lago de Genesaré e, enfim, depois de ter atravessado um longo espaço de deserto, entrava no lago Asfaltite (506-515).

Ao longo do lago Genesaré, se estendia uma região que tinha o mesmo nome, de grandes recursos naturais e de uma beleza maravilhosa. Sua fertilidade admitia qualquer cultivo e, quem a trabalhava conseguia fazer crescer ali todo o tipo de árvore e, o clima, era tão temperado que adaptava-se, também, às plantas mais variadas. As nogueiras, árvores particularmente aptas às regiões frias, ali cresciam em grande número, junto às palmeiras que necessitavam do calor e, perto delas, cresciam figueiras e oliveiras, para as quais era mais apropriado um clima mais moderado. Dir-se-ia que a natureza se tenha comprazido de um esforço tal para recolher no mesmo solo as espécies mais diversas e, que as estações se tinham enfrentado em benéfica competição, procurando cada uma se impor em tal região, com efeito, esta não só produzia estranhamente frutos tão diversos, como também os conservava. Fornecia uva e figos, delícias de reis, ininterruptamente por dez meses, enquanto os demais frutos, maduravam durante o ano todo. Além de gozar deste clima temperado, a região era irrigada por uma fonte fecunda, que a gente do lugar chamava Carfanaum. Alguns a consideravam uma veia do Nilo, porque produzia um peixe semelhante a tilápia, que vivia no lago de Alexandria. A região se estendia, ao longo da beira do lago homônimo, por 30 estádios de comprimento e 20 de largura (516-521).

Se a Galileia se sobressaía em campo agrícola e era rica em pescaria e, as pesquisas arqueológicas mostraram, também, a presença de um centro de produção de cerâmica em Kfar Hananiah, situada entre a Alta e a Baixa Galileia (conforme Meyers), a região de Jericó oferecia extraordinárias tamareiras e plantas de precioso bálsamo. Em Ant 15, 96, Flávio Josefo foi muito sintético: esta aldeia produzia bálsamo que era o produto mais precioso e crescia, somente lá e, também, palmeiras numerosas e excelentes. Em Ant 14, 54, descreveu o modo de cultivar o bálsamo: "Excelentíssimo unguento que, assim como a rosa selvagem, ao ser talhado com um sílex afiado, destila como um suco". Em Bell 4, 467-470, 474, apresenta-nos, assim, a planície de Jericó, cidade das palmeiras (conforme Dt 34, 3; Jz 1, 16): uma fonte faz prosperarem ali, jardins exuberantes e densos. As palmeiras que essa banha, são de muitas espécies. As tâmaras mais grossas, espremidas, exsudam abundante mel, não muito inferior ao outro produto das abelhas da região. Ali se recolhe o opobálsamo, o mais apreciado entre os produtos da região, o alfeneiro e o mirobálsamo e, em vista disso, não erraria em chamar esta, uma aldeia divina, na qual crescem abundantes as plantas mais ricas e mais belas. Por seus outros frutos, não seria fácil encontrar outra região no mundo que poderia ser colocada em confronto, tão grande é o rendimento da semente. Também, o clima é tão temperado que os habitantes se vestem de linho, enquanto neva no restante da Judeia. De Jerusalém, dista 150 estádios e, do Jordão, 60; a região de Jericó e à Jerusalém é desértica e pedregosa; aquela para o Jordão e o lago Asfaltite, embora menos elevada, é igualmente desértica e agreste. 
Do Mar Morto ou Asfaltite, como o chamava Flávio Josefo, o historiador judaico nos oferece esta descrição (Bell 4, 476. 478-479. 482): é amargo e infecundo, mas, pela sua leveza, mantém flutuando mesmo os objetos mais pesados que joguem dentro dele, de modo que é difícil imergir-se, mesmo para quem o desejar. Um espetáculo maravilhoso é também, a mudança de sua cor, que muda três vezes ao dia, com o diverso refletir dos raios do sol. Ademais, faz aflorar em muitos lugares, negras massas de betume, que flutuam, semelhantes por figura e grandeza a touros sem cabeça. 0 comprimento deste lago é de 580 estádios - estendendo-se até Zoara, na Arábia - e, sua largura, é de 150.

A descrição de Jerusalém é detalhada em Bell 5, 136 - 146: a cidade estava construída sobre duas colinas afrontadas e, separadas entre si, por um vale, em direção deste, as casas descem em degraus. Das duas colinas, a que formava a cidade alta era notoriamente mais elevada e, tinha no cimo, uma esplanada mais ampla; por sua forte posição, essa recebeu precisamente o nome de "Fortaleza" do Rei Davi, o pai de Salomão, que foi o primeiro a construir o Templo, enquanto nós a denominamos "praça superior". A segunda colina, é a que se denomina "Akra" e, que formava parte da cidade baixa, com sua forma recurvada nas extremidades. De fronte a esta, existia uma terceira colina, originalmente, mais baixa do que o Akra, do qual antigamente estava separada por outro amplo vale. Mais tarde, durante seu reino, os Asmoneus, encheram tal vale, querendo conectar cidade e Templo e, ao mesmo tempo, fizeram descer a altura do Akra, de modo que, também, sobre essa, prevalecesse o edifício do Templo. 0 vale dos Queijeiros, que dissemos, está entre a cidade alta e a baixa, chegando até Siloé, como chamavam aquela fonte riquíssima de água doce. As duas colinas da cidade terminavam ao externo em precipícios profundos e, pelos barrancos de ambos os lados, não havia possibilidade de acesso (136-141).

O mais antigo dos três muros era inexpugnável por causa dos precipícios da altura, sobre os quais fora levantado; além da vantagem da posição natural, tinha sido construído solidamente e, não somente, Davi e Salomão, mas também, seus sucessores tinham dedicado seus cuidados a ele. Começando ao norte da torre, chamada Hípico, se inclinava até o Xisto, depois passava pelo edifício do Conselho e terminava no Pórtico ocidental do Templo. Do outro lado, começando do mesmo ponto e, olhando o ocidente, o muro corria através do lugar chamado Betso, até a Porta dos Essênios, depois se estendia ao sul, até envolver a Fonte de Siloé, donde, voltando ainda para o leste, para a Piscina de Salomão e, passado o lugar chamado Ofel, chegava ao Pórtico oriental do Templo. 0 segundo muro, começava da Porta do primeiro muro, que chamavam Genná e, singindo somente a parte setentrional da cidade, chegava até a fortaleza Antônia (142-146).

Flávio Josefo faz também uma breve alusão ao "monte dito das oliveiras, que surge em frente da parte oriental da cidade, da qual a separa um profundo vale chamado Cedron" (Bell 5, 70).

Confinantes ou até mesmo dentro da terra de Israel, não poucas cidades de cunho helenista, verdadeiras e próprias poleis, gozavam de um estatuto administrativo especial, mesmo se, às vezes, 
alguma dessas estavam inscritas no reino dos Herodes. Seus nomes: Cesareia Marítima, Sebaste - a antiga Samaria -, sobretudo, a Decápoles, na qual devem ser mencionadas as cidades de Gerasa, Gadara, Abila, Pela, que contudo, não formavam uma federação (conforme Schürer, II, p.p. 119-233).

Discute-se sobre o número dos habitantes da Palestina. Foraboschi reporta os dois extremos: 500 mil - segundo J. Jeremias e, 5 milhões, segundo J. Juster. Para o estudioso israelita Arye Ben-David, citado por Stegemann (Gli esseni, p. 201), em todo o mundo viviam, então, de 6,5 a 7 milhões de hebreus, dos quais 1 a 1,2 milhões habitavam na Palestina. Para a população da Galileia, Meyers fala de 200 aldeias com 500 habitantes cada uma, em média e, de alguns centros um pouco mais populosos, além das duas grandes cidades de Séforis e Tiberíades, para um total de 150 a 175 mil habitantes (BARBAGLIO, 2011).

\subsection{A Pregação de Cristo Na Palestina}

\subsubsection{O Encontro de Cristo com João Batista}

No tempo de Jesus, o que levava multidões ao vale árido cortado pelo rio salobro que corria do Mar da Galileia até o Mar Morto, dizia respeito à crença judaica no arrependimento. No tempo de Jesus esse era o ponto mais baixo do planeta. Portanto, perguntava-se, até que ponto da precisa descida era suficiente para ir em busca do perdão junto à um homem rústico que vestia peles de animais e se alimentava de gafanhotos? 0 que levou Jesus a procurar João Batista? Não foi o roteiro escrito por Deus, na forma como em geral as pessoas liam os Evangelhos. Em sua compreensão de si mesmo, Jesus deve ter achado que precisava ouvir o que João pregava que precisava ter o que João oferecia.

Em sua resistência à Roma, a esperança de Israel era o arrependimento. Como judeu, João dizia que o reino de Deus triunfando sobre Roma, ocorreria quando o povo derrotado e dividido se unisse na volta para o seu Senhor - um triunfo prometido na história, não no misticismo. João dizia que o restabelecimento da autoridade de Deus era uma possibilidade no futuro próximo e, que quanto maior o número dos que acolhessem e compreendessem a sua mensagem, com maior probabilidade, ela poderia concretizar-se. João era um homem singular.

A primeira surpresa da história ocorreu quando Jesus se apresentou a João para o batismo de arrependimento e, supostamente, o que aconteceu, então, surpreendeu tanto a Jesus, como a qualquer outro. Os relatos evangélicos dizem que os céus se abriram e nada menos do que a voz de Deus se fez ouvir, declarando que Jesus era o próprio filho amado de Deus. Jesus, viu sua percepção de si mesmo desfazer-se: ele era aprovado por Deus. Não havia dúvida quanto à necessidade de merecer a aprovação de Deus. Jesus simplesmente a tinha. Essa linguagem de teofania - "Este é o meu filho amado" - e, esse simbolismo - a pomba do espírito de Deus descendo - tinham, simplesmente, o 
objetivo de transmitir a epifania vivida por Jesus, na presença de João, a revelação definidora da vida de Jesus.

Por outro lado, a mensagem de Jesus era também, inevitavelmente, política. Mesmo sua mensagem de amor ao próximo - de amor ao inimigo - tinha o objetivo de estimular os judeus da sua época, a abandonarem sua divisão sectária e a voltar à unidade sagrada de povo de Israel, eleito de Deus. Não mera mensagem de conteúdo emocional, o amor que Jesus pregava era a solidariedade e, para um império que dependia, como sempre acontecia com todos os impérios, de divisões destrutivas do povo ocupado - vizinho contra vizinho - era impensável permitir o desenvolvimento incontrolado dessa solidariedade.

Nesta época, chegaram notícias de que João Batista, mentor e inspiração de Jesus, fora executado por ordem de Herodes - decapitado, sendo sua cabeça apresentada numa bandeja, durante um banquete no palácio. Foi nessa ocasião que ficou evidente que Jesus pisava na zona de morte do império. Esse ato de sadismo violento, cujo aspecto grotesco perde-se na familiaridade das histórias da Bíblia, definiu o futuro que aguardava Jesus. Herodes estava esperando, também, Jesus. E, Jesus sabia disso, o que se comprovou numa frase simples que descreveu sua reação: "Ouvindo isso, Jesus partiu dali, de barco, para um lugar deserto, onde pudesse ficar sozinho". Desse momento em diante, Jesus compreendeu que o caminho em que ele foi posto, seu encontro com João Batista, no Rio Jordão, o estava levando diretamente para a morte.

Depois de saber, na presença de João, que ele era radicalmente aceito por Deus, aquele a quem chamava Pai, com a morte de João, Jesus soube que essa aceitação significava que não havia nada a temer na morte, porque a morte não afetava o amor de Deus. Aqui estava o ponto crítico: é a perspectiva da morte que faz os humanos suspeitarem do seu valor moral, razão pela qual eles temem a morte, mas, Jesus, com seu valor asseverado pelo Pai, ficou livre desse medo. Foi isso que o tornou a figura transcendente em quem as pessoas começaram a reconhecer o Filho de Deus. A libertação do medo da morte tornou-se a sua mensagem e, o modo como ele falava dessa libertação, era declarar que, o Reino de Deus - o Deus que tudo aceita, o Deus misericordioso - já havia começado. O Reino de Deus está dentro de ti.

Todavia, a contradição máxima dessa mensagem era a ocupação de Israel por Roma, que enfatizava a insignificância do povo subjugado e se aproveitava do seu medo da morte. Era inconcebível que Jesus, digno e livre do medo, não desafiasse Roma, o que significa, primeiro, desafiar o fantoche de Roma, o assassino de João, a enfrenta-lo. Quando avisado de que Herodes queria mata-lo, Jesus respondeu, "Ide dizer a essa raposa: Eis que eu expulso demônios". Que demônios? Os demônios que deixavam o povo com medo. 0 poder de Herodes dependia da aquiescência de um povo preso pelas garras demoníacas do medo. "Não tenhais medo", repetia Jesus incessantemente. E, quanto mais ele repetia, mais o povo se aliava a ele. E, à medida que essa solidariedade crescia, mais direto se tornava o seu desafio - não ao governante subalterno, mas, à própria Roma. Só havia um lugar onde 
esse desafio podia receber adesão total e, depois da morte de João, Jesus soube qual era, a arena do império. Ele não tinha outra saída senão entrar nela. Jerusalém. Jesus vai a Jerusalém. 0 restante da história é consequência e todos conhecem bem (CARROLL, 2006).

\subsubsection{A Pregação de Cristo na Galileia}

Ao contrário de Belém - um lugar carregado de simbolismo e história por ser a Cidade de Davi - Nazaré, na Galileia, era desprovida de tais associações. Não é sequer mencionada no Antigo Testamento. Os Evangelhos dizem que foi a cidade onde Jesus viveu na infância, sendo ele habitualmente conhecido como Jesus de Nazaré. A Galileia (um dos quatro distritos administrativos da Palestina romana) tinha a reputação de ser mais liberal que Jerusalém. 0 helenismo se radicou mais facilmente ali, do que na Judeia. Havia, portanto, uma significativa atmosfera cosmopolita.

Embora grande parte do ministério inicial de Jesus tenha se concentrado na Galileia, existem poucos relatos de seu contato com estrangeiros ou oficiais romanos. Apenas ocasionalmente ele saiu das fronteiras da região para ir à Decápoles ou a Tiro e Sidônia. Seu meio social era a sinagoga e seus companheiros judeus da Galileia. O Evangelho de João registra que Jesus fez várias visitas à Jerusalém, normalmente, para festas judaicas (ex.: João 2: 13; 5: 1; 10: 22); os outros Evangelhos registram apenas uma viagem à Jerusalém - a última e fatídica visita de Jesus. Pode sair alguma coisa boa de Nazaré? É um deboche de Natanael (João 1: 45-46). Obviamente, para os cristãos isto soava irônico seu Senhor era Jesus de Nazaré. A expressão "Galileia das Nações" (Isaías 9: 1) ou "Galileia dos Gentios" (Mateus 4: 15) é usada porque a mensagem cristã universal surgiu ali. Portanto, do contraste com Jerusalém que é condenada por ser o lugar onde Jesus morreu (Mateus 23: 37).

Há relatos de que Jesus tenha sido rejeitado em sua terra natal (Lucas 4: 16-30). Os cidadãos de lá tentaram matá-lo. Até sua família o rejeitou, julgando-o louco (Marcos 3: 21), e seus irmãos não acreditaram nele (João 7: 5). Talvez por isso, Jesus decidiu se estabelecer em Cafarnaum, no Mar da Galileia (Mateus 4: 13). Há muitas referências sobre "Jesus em sua casa". Contudo, em sua lista de infortúnios, em Mateus 11: 23, Cafarnaum é condenada por Jesus como sendo ainda pior que Sodoma. Escavações recentes descobriram uma sinagoga no sítio de Cafarnaum.

Outra cidade da Galileia mencionada no Novo Testamento é Betsaida. Ela foi construída por Herodes, o Grande e, se tornou uma cidade predominantemente de gentios. Era, no entanto, a cidade natal de três apóstolos: Felipe, Pedro (também chamado de Simão) e André, de acordo com João 1: 44; 12: 21, e é mencionada diversas vezes nos Evangelhos. A descrença de seus moradores foi denunciada por Jesus (Mateus 11: 21) (BEITZEL, 2009). 


\subsubsection{O Sermão da Montanha}

O Sermão da Montanha é um discurso de Jesus Cristo que pode ser lido no Evangelho de Mateus (Caps. 5-7) e no Evangelho de Lucas (Fragmentado ao longo do livro). Nestes discursos, Jesus profere lições de conduta e de moral, observando os princípios que normatizam e orientam a verdadeira vida cristã, uma vida que conduz a humanidade ao Reino de Deus e, que põe em prática a vontade de Deus, que leva à verdadeira libertação do homem. Estes discursos podem ser considerados como um resumo dos ensinamentos de Jesus a respeito do Reino de Deus, do acesso ao Reino e da transformação que esse Reino produz.

MAPA 3 - O LOCAL DO SERMÃO DA MONTANHA

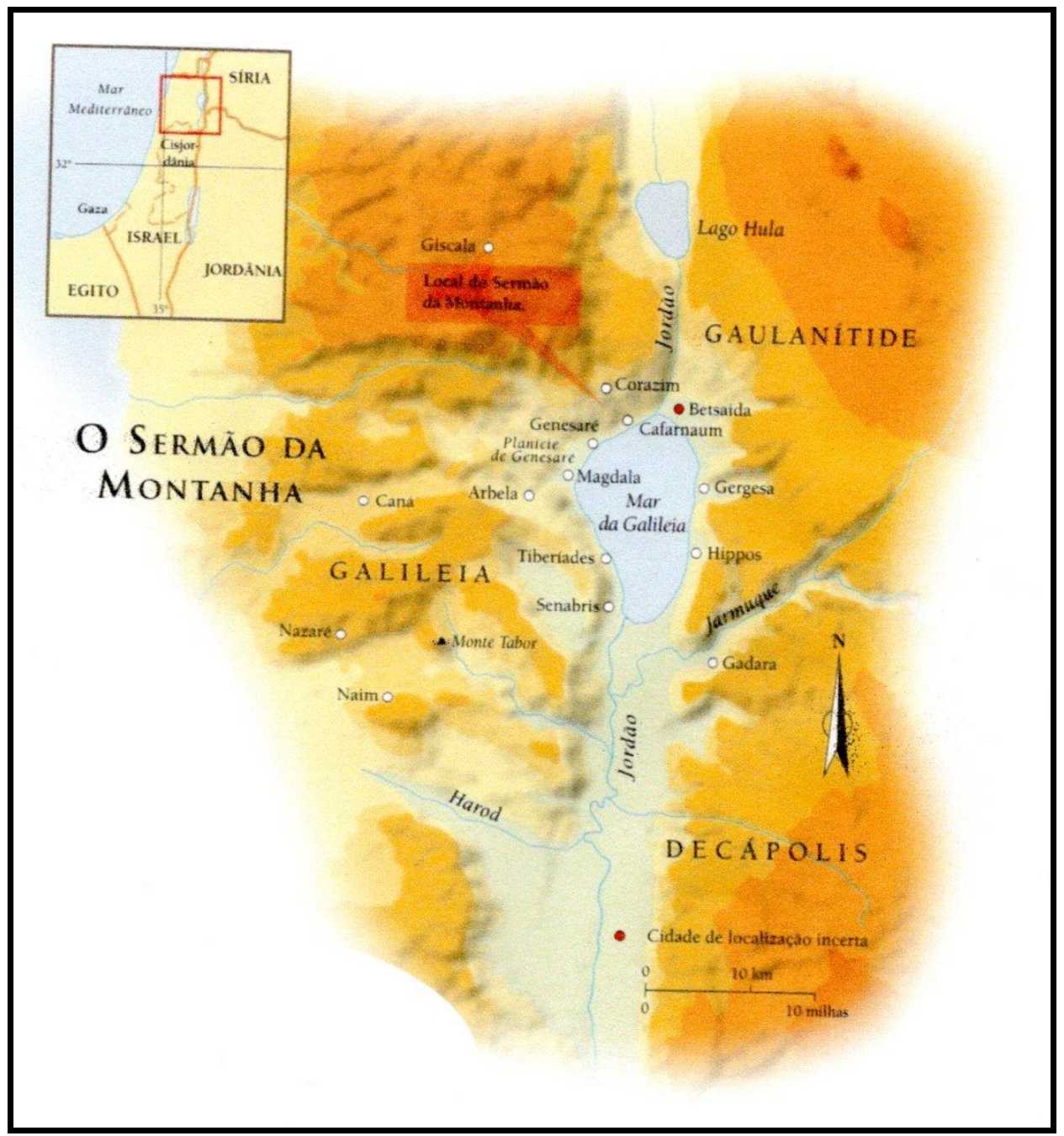

Fonte: Beiltzel, p. 427, 2009.

Além de importantes princípios ético-morais, pode-se notar grandes revelações, pois aquilo que muitas vezes é tido por ruim, por desagradável, diante de Deus é o que realmente vai levar muitos à verdadeira felicidade. Esta passagem forma um paradoxo, contrariando a ideia de muitos e, mais 
uma vez, mostrando que "... Deus não vê como o homem vê, o homem vê a aparência, mas, Deus sonda o coração" (I Samuel 16.7).

No Sermão da Montanha, o evangelista Mateus está apresentando Jesus como o novo Moisés, daí o discurso ser proferido numa montanha (talvez, apenas uma colina), pois, Moisés tinha recebido os 10 Mandamentos no monte Sinai. Entretanto, Jesus afirmou que não veio para abolir a Lei ou os Profetas, mas sim, cumprir na sua íntegra (Mt 5.17).

Na introdução narrativa, o evangelista descreve que Jesus, vendo aquelas multidões, subiu à montanha e sentou-se e, seus discípulos aproximaram-se dele e, é aí que Ele começou a pregar o seu famoso sermão ao ar livre (Mt 5.1-2).

As Bem-aventuranças são o anúncio da verdadeira felicidade, porque proclamam a verdadeira e plena libertação e não o conformismo ou a alienação. Elas anunciam a vinda do Reino de Deus, através da palavra e ação de Jesus, que tornam a justiça divina presente no mundo. A verdadeira justiça para aqueles que são inúteis, pobres ou incômodos para uma estrutura de sociedade baseada na riqueza que explora e no poder que oprime. As Bem-aventuranças revelam, também, o carácter das pessoas que pertencem ao Reino de Deus, exortando as mesmas a seguir este carácter exemplar.

Resumindo e usando as palavras de Jesus, as Bem-aventuranças nos ensinam o fim último ao qual Deus nos chama: o Reino de Deus, a visão de Deus, a participação na natureza divina, a vida eterna, a filiação divina, o repouso em Deus.

- Bem-aventurados os pobres por espírito, porque deles é o Reino dos Céus.

- Bem-aventurados os que choram, porque serão consolados.

- Bem-aventurados os mansos, porque possuirão a terra.

- Bem-aventurados os que têm fome e sede de justiça, porque serão saciados.

- Bem-aventurados os misericordiosos, porque alcançarão misericórdia.

- Bem-aventurados os puros de coração, porque verão Deus.

- Bem-aventurados os Defensores da Paz, porque serão chamados filhos de Deus.

- Bem-aventurados os que são perseguidos por causa da justiça, porque deles é o Reino dos Céus.

- Bem-aventurados sereis quando vos caluniarem, quando vos perseguirem e disserem falsamente todo o mal contra vós por causa de Mim.

- $\quad$ Alegrai-vos e exultai, porque será grande a vossa recompensa nos céus, pois assim perseguiram os profetas que vieram antes de vós.

No que diz respeito ao Sal da Terra e a Luz do Mundo, Jesus, através das metáforas de Sal e de Luz, revela a enorme força do testemunho e a importante função dos discípulos, especialmente dos pregadores, que é, sobretudo, preservar e proteger a humanidade contra as influências malignas da 
corrupção e da maldade (a função do Sal) e, ajudar a humanidade a conhecer, através da sua fé e seu bom exemplo iluminadores, o caminho da salvação (a função da Luz).

"Vós sois o sal da terra. Ora, se o sal perde o sabor, com que lhe será restituído o sabor? Para nada mais serve senão para ser lançado fora e calcado pelos homens. Vós sois a Luz do mundo. Não se pode esconder uma cidade situada sobre uma montanha, nem se acende uma luz para colocá-la debaixo do alqueire, mas sim, para colocá-la sobre o candeeiro, a fim de que brilhe a todos os que estão em casa. Assim, brilhe vossa luz diante dos homens, para que vejam as vossas boas obras e glorifiquem vosso Pai que está nos céus".

Reinterpretando a Lei de Deus, Jesus revaloriza e reinterpreta, por vezes de forma antitética, a Lei de Deus na sua íntegra, particularmente dos 10 Mandamentos, tendo por objetivo levá-los à perfeição (Mateus 5:48):

“Não julgueis que vim abolir a Lei ou os Profetas. Não vim para os abolir, mas sim, para leválos à perfeição. Pois em verdade vos digo: passará o céu e a terra, antes que desapareça um jota, um traço da lei. Aquele que violar um destes mandamentos, por menor que seja e, ensinar assim aos homens, será declarado o menor no Reino dos Céus. Mas, aquele que os guardar e os ensinar será declarado grande no Reino dos Céus. Digo-vos, pois, se vossa justiça não for maior que a dos escribas e fariseus, não entrareis no Reino dos Céus".

No que tange a oferta à outra face, Jesus, a seguir à reinterpretação da Lei de Deus, começa a condenar a ostentação na prática de três obras fundamentais do Judaísmo, que são a esmola, o jejum e a oração. Ele não pretende condenar a observância fiel e honesta destas obras boas e o bom exemplo que estas ações produzem, mas somente, o vão desejo de ostentar em frente de outras pessoas. Ele alerta para o fato de, se a finalidade das pessoas que praticam estas obras é ostentar, eles já foram recompensados na Terra por outros homens que as elogiaram.

“Guardai-vos de fazer vossas boas obras diante dos homens, para serdes vistos por eles. Do contrário, não tereis recompensa junto de vosso Pai que está no céu".

"Quando, pois, dás esmola, não toques a trombeta diante de ti, como fazem os hipócritas nas sinagogas e nas ruas, para serem louvados pelos homens. Em verdade eu vos digo: já receberam sua recompensa. Quando deres esmola, que tua mão esquerda não saiba o que fez a direita. Assim, a tua esmola se fará em segredo; e teu Pai, que vê o escondido, recompensar-te-á".

"Quando jejuardes, não tomeis um ar triste como os hipócritas, que mostram um semblante abatido para manifestar aos homens que jejuam. Em verdade eu vos digo: já receberam sua recompensa. Quando jejuares, perfuma a tua cabeça e lava o teu rosto. Assim, não parecerá aos homens que jejuas, mas somente, a teu Pai, que está presente ao oculto; e teu Pai, que vê num lugar oculto, recompensar-te-á".

"Quando orardes, não façais como os hipócritas, que gostam de orar de pé nas sinagogas e nas esquinas das ruas, para serem vistos pelos homens. Em verdade eu vos digo: já receberam sua 
recompensa. Quando orares, entra no teu quarto, fecha a porta e ora ao teu Pai em segredo; e teu Pai, que vê num lugar oculto, recompensar-te-á. Nas vossas orações, não multipliqueis as palavras, como fazem os pagãos que julgam que serão ouvidos à força de palavras. Não os imiteis, porque vosso Pai sabe o que vos é necessário, antes que vós lho peçais".

Durante o seu discurso sobre a oração, Jesus deu aos homens uma célebre oração, o PaiNosso, que se trata de um modelo para ensiná-los como orar corretamente.

"Pai Nosso, que estais no céu, santificado seja o vosso nome; venha a nós o vosso Reino; seja feita a vossa vontade, assim na terra como no céu. 0 pão nosso de cada dia nos dai hoje; perdoai-nos as nossas ofensas, assim como nós perdoamos aos que nos ofenderam; e não nos deixeis cair em tentação, mas, livrai-nos do mal".

Jesus afirma também que se perdoardes aos homens as suas ofensas, vosso Pai Celeste, também, vos perdoará. Mas, se não perdoardes aos homens, tampouco vosso Pai vos perdoará (Mt 6, 14-15).

Também sobre a oração, Jesus exorta, por fim aos seus discípulos, que deviam sempre ter confiança na oração e, particularmente em Deus, porque vosso Pai Celeste dará boas coisas aos que lhe pedirem durante a oração.

“Pedi e se vos dará. Buscai e achareis. Batei e vos será aberto. Porque todo aquele que pede, recebe. Quem busca, acha. A quem bate, abrir-se-á. Quem dentre vós dará uma pedra a seu filho, se este lhe pedir pão? E, se lhe pedir um peixe, dar-lhe-á uma serpente? Se vós, pois, que sois maus, sabeis dar boas coisas a vossos filhos, quanto mais vosso Pai Celeste dará boas coisas aos que lhe pedirem".

No que concerne ao materialismo e providência divina, Jesus, condenando indiretamente o materialismo, exorta os seus discípulos para não preocupar demasiado com os seus bens e as suas necessidades materiais, mas sim, preocupar-se mais e, em primeiro lugar, em guardar "tesouros no céu", para preparar o acesso ao Reino de Deus. Sobre a riqueza, Jesus alerta os seus discípulos para o fato de ser impossível servir ao mesmo tempo a "Deus e à riqueza". E, relativamente às necessidades materiais dos homens e às suas preocupações cotidianas, Jesus apela para a confiança na Providência divina, afirmando que "vosso Pai Celeste sabe que necessitais de tudo isso" e "que o dia de amanhã terá as suas preocupações próprias". A cada dia basta o seu cuidado (Mt 6, 19-34).

"Não ajunteis para vós tesouros na terra, onde a ferrugem e as traças corroem, onde os ladrões furtam e roubam. Ajuntai para vós tesouros no céu, onde não os consomem nem as traças, nem a ferrugem e, os ladrões não furtam, nem roubam. Porque onde está o teu tesouro, lá também está teu coração".

"Ninguém pode servir a dois Senhores, porque ou odiará a um e amará o outro, ou dedicar-seá a um e desprezará o outro. Não podeis servir a Deus e à riqueza”.

"Não vos aflijais, nem digais: Que comeremos? Que beberemos? Com que nos vestiremos? São os pagãos que se preocupam com tudo isso. Ora, vosso Pai Celeste sabe que necessitais de tudo isso. 
Buscai em primeiro lugar, o Reino de Deus e a sua justiça e, todas estas coisas vos serão dadas em acréscimo. Não vos preocupeis, pois, com o dia de amanhã: o dia de amanhã terá as suas preocupações próprias. A cada dia basta o seu cuidado".

Quanto ao julgamento dos outros, Jesus, condena também, aqueles que julgam os outros, mas, não sabem julgar-se a si próprio, não conseguindo reconhecer os seus próprios erros.

"Não julgueis e, não sereis julgados. Porque do mesmo modo que julgardes, sereis também, julgados e, com a medida com que tiverdes medido, também vós sereis medidos. Por que olhas a palha que está no olho do teu irmão e não vês a trave que está no teu? Como ousas dizer a teu irmão: Deixame tirar a palha do teu olho, quando tens uma trave no teu? Hipócrita! Tira primeiro a trave de teu olho e, assim, verás para tirar a palha do olho do teu irmão".

No que tange à regra de ouro, Jesus assinala: "Tudo o que quereis que os homens vos façam, fazei-o vós a eles. Esta é a Lei e os Profetas".

Referindo-se ao verdadeiro discípulo e as suas dificuldades, Jesus alerta para as dificuldades dos seus discípulos, que pretendem ser os verdadeiros filhos de Deus, que irão encontrar no caminho estreito e apertado que conduz à vida eterna e ao Reino de Deus (o chamado caminho da vida).

"Entrai pela porta estreita, porque larga é a porta e espaçoso o caminho que conduzem à perdição e numerosos são os que por aí entram. Estreita, porém, é a porta e apertado o caminho da vida e raros são os que o encontram".

Jesus também alerta os homens para o fato de só reconhecerem que Ele é o Senhor não é suficiente para eles serem salvos e reconhecidos como os seus verdadeiros discípulos, mas sim, necessitando também, de fazer verdadeiramente a vontade de Deus.

“Nem todo aquele que me diz - Senhor, Senhor - entrará no Reino dos Céus, mas sim, aquele que faz a vontade de meu Pai que está nos céus. Muitos me dirão naquele dia: Senhor, Senhor, não pregamos nós em vosso nome e, não foi em vosso nome que expulsamos os demônios e fizemos muitos milagres? E, no entanto, eu lhes direi: Nunca vos conheci. Retirai-vos de mim, operários maus!".

Ao se referir aos falsos profetas, Jesus aconselhou os seus discípulos a acautelarem-se dos falsos profetas, que apesar de parecerem "ovelhas", são na verdade uns "lobos arrebatadores" e maus, que têm por finalidade, desorientar as pessoas e levá-las à perdição.

“Guardai-vos dos falsos profetas. Eles vêm a vós disfarçados de ovelhas, mas por dentro, são lobos arrebatadores. Pelos seus frutos os conhecereis. Colhem-se, porventura, uvas dos espinhos e figos dos abrolhos? Toda árvore boa dá bons frutos; toda árvore má dá maus frutos. Uma árvore boa não pode dar maus frutos; nem uma árvore má, bons frutos. Toda árvore que não der bons frutos será cortada e lançada ao fogo. Pelos seus frutos os conhecereis".

Falando sobre edificar sobre a rocha, Jesus, concluindo o seu sermão, exorta por fim aos seus discípulos para, depois de escutar as suas palavras e ensinamentos, pô-los verdadeiramente em prática, para serem semelhantes a um "homem prudente que edificou sua casa sobre a rocha". A rocha 
é resistente a todas as tempestades, por isso, ela é uma excelente base ou fundamento para sustentar a casa, assemelhando-se à Palavra de Deus, que serve como fundamento e sustenta todas as pessoas que põe-na em prática, protegendo-as e ajudando-as a ultrapassar todos os obstáculos e dificuldades que elas poderão encontrar nas suas vidas.

"Aquele, pois, que ouve estas minhas palavras e as põe em prática é semelhante a um homem prudente, que edificou sua casa sobre a rocha. Caiu a chuva, vieram as enchentes, sopraram os ventos e investiram contra aquela casa; ela, porém, não caiu, porque estava edificada na rocha. Mas, aquele que ouve as minhas palavras e não as põe em prática é semelhante a um homem insensato, que construiu sua casa na areia. Caiu a chuva, vieram as enchentes, sopraram os ventos e investiram contra aquela casa; ela caiu e grande foi a sua ruína".

No fim narrativo, o evangelista São Mateus descreve que a multidão que foi ouvir o sermão "ficou impressionada com a sua doutrina", porque Jesus "a ensinava como quem tinha autoridade e não como os escribas" (Mateus 7:28-29).

\section{CONSIDERAÇÕES FINAIS: A INTERPRETAÇÃO DO DISCURSO DE CRISTO, NO SÉCULO XXI}

Excepcionalmente, o término do presente estudo será destinado à reflexão alusiva à natureza do discurso de Cristo, interpretado no início do século XXI. O conteúdo da sua pregação será levado a termo, visualizando o Cristo histórico, discutindo com os seus discípulos e o povo de sua época e, passando aos mesmos, o que Ele considerava importante para que a humanidade tivesse um projeto de vida baseado no bem, na verdade e na justiça.

Lendo-se, atentamente, os quatros Evangelhos, percebe-se o enorme legado espiritual, ético e moral deixado por este protagonista marcante. Ele esclareceu, muito bem, aspectos proeminentes da vida dos seres humanos: o amor, a fé, a esperança, a misericórdia, o perdão, a generosidade, a solidariedade, a justiça social e a paz.

Ao se tomar a produção global de Jesus, pode-se ver bem claramente - fato escondido pela exegese tradicional - que a prática discursiva de Jesus foi feita para subverter, radicalmente, o sistema ideológico-religioso que constituía o sistema dominante, na formação social de Israel. Esse sistema centrava-se no Templo, sendo por ele ligado aos outros sistemas da estrutura social. 0 objetivo da prática de Jesus era, precisamente, a eliminação do Templo e, juntamente com ele, do sistema de inclusão-exclusão, organizado pela Lei. Colocando em questão o Templo e a Lei, ele estava visando o sistema total.

A leitura da estrutura social realizada por Jesus era uma leitura radical. Ela se desenvolvia a partir do "dever-ser" absoluto próprio ao ideal messiânico levado a seu ponto máximo. Nesse sentido, Jesus tinha consciência de propor um programa de libertação radical; senão se temesse ser interpretado superficialmente, se poderia dizer que, se tratava de um programa utópico de libertação. 
Com efeito, a prática discursiva de Jesus negava os três pilares sobre os quais repousava toda a estrutura da dominação das sociedades pré-capitalistas de classe, para além das suas formas históricas concretas: o poder, a riqueza e a religião-ideologia. O Templo repousava nesses três pilares. E, Jesus propôs a sua negação absoluta. Diz-se "negação absoluta" porque o discurso de Jesus não visava, apenas, contestar o poder, a riqueza e a religião-ideologia por si mesmos, mas sim, como eixos sobre os quais a sociedade se constrói.

Mas, sendo assim, o que resta da sociedade e da história? Resta um profundo desespero, expresso paradoxalmente na esperança escatológica, isto é, "uma estratégia radicalmente coletivista". Vários estudiosos falam de uma estratégia radicalmente coletivista, que só poderia tornar-se efetiva pela transformação do modo de produção subasiático, em virtude do fechamento do modo de produção escravagista, sendo assim condenada a ser uma estratégia não revolucionária. Nesse ponto, não se pode estar de acordo com tais estudiosos. Acredita-se que só se pode comparar a prática discursiva de Jesus com uma estratégia radicalmente coletivista, situando-a no ponto em que radicalmente coletivista coincide com a tradição profética, que alguns consideraram mais próxima de um certo anarquismo, em virtude da crítica radical de todos os poderes que percorre a tradição profética de Israel e, cujo impacto continuaria a atravessar a história, como fonte permanente de revolta.

Isso a se apresentar a hipótese de que a prática discursiva de Jesus não exerceu diretamente uma função orgânica, no sentido de Gramsci (intelectual orgânico das classes subalternas) nenhuma função ideológica, no sentido de Althusser (ideologia como mascaramento da estrutura das relações sociais), se bem que levasse em germe dentro de si essas duas funções. Ela não exerceu uma função orgânica em relação à sua base social. Tal função foi muito mais desempenhada pelo farisaísmo e, numa medida bastante ambígua, pelo zelotismo, não por Jesus. 0 movimento zelota poderia ser considerado como orgânico, em relação à sua classe, na medida em que lhe dava consciência de sua situação objetiva de opressão e, tentava organiza-la como classe em luta, até a morte mais cruel. Devese acrescentar, porém, que ele tinha uma outra dimensão: o seu projeto de restauração de uma ordem real. A prática discursiva de Jesus já não alcançava o mesmo efeito, precisamente por seu caráter, ao mesmo tempo exterior aos movimentos sociais e mais fundamental. Ele fazia com que se tomasse consciência da opressão, mas, tratava de levar essa consciência a um nível mais radical, o nível do sentido. E, nesse esforço, já não correspondia em absoluto à expectativa de seus interlocutores. Daí a distância entre Jesus e o movimento zelota por um lado e a progressiva diminuição do apoio popular a Jesus, por outro.

A prática de Jesus também não exerceu uma função ideológica, no sentido a que se refere, pois, não continha uma legitimação da estrutura de dominação, nem uma justificação da opressão. 0 questionamento do presente, a partir do ideal messiânico, não constituiu um mecanismo de resignação, face à ordem existente, nem de sua sublimação em ações simbólicas. A prática de Jesus até 
a sua execução o mostra desempenhando uma função diferente. 0 fato de insistir em um sentido último, para além do presente, também poderia afastar a atenção do presente e projetar as contradições de sociedade atual em uma utopia intemporal, dando lugar, assim, à recompensa póshistórica das classes subalternas e à auto-justificação das classes dominantes. Entretanto, essa tentativa só se manifestou com a institucionalização do cristianismo.

O que era, então, a prática discursiva de Jesus? 0 conceito de ideologia arbitrária de Gramsci se parece útil para tentar a formulação de uma hipótese. A ideologia arbitrária é obra de um indivíduo ou grupo que não encara fundamentalmente os conflitos fundamentais que caracterizam a estrutura de uma formação social historicamente dada, fazendo-o mais geralmente no absoluto, daí a noção de arbitrária, em relação à sociedade imediata. Essa ideologia, porém, pode ser orgânica para certas classes, como, por exemplo, as classes subalternas. Em parte, a produção ideológica de Jesus parece corresponder a esse modelo. Isso explicaria, não somente, a ausência ou presença mínima do novo movimento nas crônicas da época, mas também, o abandono popular e o claro esforço de Jesus, no sentido de abrir sua ação para além das fronteiras religiosas de Israel, levando-a às massas pagãs vizinhas. 0 Êxodo para os pagãos, que, de acordo com alguns estudiosos, encontra particularmente no Evangelho de Marcos, constitui provavelmente a consequência social lógica não só da subversão do sistema ideológico dominante em Israel, como também, de uma marginalidade no interior da sociedade judia.

Em resumo, em seu nascimento, o fenômeno cristão era uma expressão, ao nível simbólico da situação de opressão das massas marginalizadas do processo de produção, de certas camadas do proletariado urbano e rural e, mesmo de uma parcela da pequena burguesia. Por essa razão, nasceu enraizado em uma classe social determinada e, exerceu uma função ambígua, no seio dessas classes, em virtude do caráter fundamentalmente radical de seu protesto, que se vinculava à tradição anárquico-utópica do profetismo e de seu ideal messiânico.

Isso se coloca diante da realidade social: concretamente, diante de um de seus invariantes mais fundamentais, o processo de institucionalização. Em uma sociedade de classes, tal processo só pode tomar uma direção funcional, em relação à estrutura social existente, já que são as práticas dos protagonistas que reproduzem as relações sociais e transformam suas representações em sistemas generalizados. A utilização da religião pelas classes dominantes segue, normalmente, esse caminho.

Por seu turno, toda expressão das classes subalternas ou daquelas que expressam de uma ou outra forma suas aspirações, só pode ser crítica diante do poder institucionalizado, desembocando na utopia, no campo simbólico. Mas, também, nesse caso, há numerosas possibilidades de concretização.

A análise da sociedade palestina permitiu constatar que a função da religião superava evidentemente aquilo que, hoje, é chamado radicalidade religiosa. 0 sobrenatural, portanto, estava presente por toda a parte e o Templo, símbolo e lugar da presença divina era ao mesmo tempo, o 
centro do poder político e econômico. Por conseguinte, deve-se colocar nessa situação para compreender os acontecimentos da época.

Assim, na medida em que Jesus tomou posição em favor dos pobres, precisa-se saber quem eram os pobres na Palestina daquela época. A oposição ao grupo dos saduceus ou dos fariseus tinha um significado maior do que o puramente religioso. A escolha dos apóstolos é um fato simbolicamente significativo, em relação à sociedade da época. 0 fato de Ele ter anunciado um messianismo que não era o da restauração davídica, constitui, evidentemente, um fato cheio de significado sócio-político, da mesma forma que a condenação radical do poder simbólico religioso, que se traduziu, sobretudo, pela subversão dos eixos ideológicos fundamentais, o do puro-impuro, o de rico-pobre, o da plebepoderoso.

Tudo isso, situado em uma sociedade de classes pré-capitalista, reveste-se de um significado preciso. Um indicador, por exemplo, é o fato de ter os imperativos religiosos debaixo e, não do alto da escala sócio-religiosa, como isso se manifestou na atitude de Jesus, em relação ao sábado ou ao jejum. A ideia de destruição do Templo por Ele levantada não pode deixar de levar em conta o significado do Templo como símbolo fundamental de toda a sociedade e, não somente, como expressão religiosa. Sem dúvida, Jesus situou-se fundamentalmente no campo religioso, mas este campo na sociedade palestina, possuía uma ressonância muito maior do que em nossas sociedades contemporâneas.

Também é interessante notar, que a morte de Jesus foi resultado de uma coalisão entre as forças do Império Romano, a elite social judia (Sumo Sacerdote), saduceus, os fariseus e a plebe que escolheu Barrabás. Assim, parece que a mensagem de Jesus colocava-se além de todos os projetos que esses diversos grupos sociais poderiam ter e, que a subversão da ordem social que sua mensagem e prática significavam, bem compreendida pelos diversos grupos que o condenaram à morte, ia mais longe do que uma referência às crenças religiosas e uma reorganização da ordem existente. À propósito, não se poderia dizer que o projeto fundamental de Cristo rumava no sentido de uma utopia, que em linguagem moderna poderia expressar em termos da criação de uma sociedade sem classes?

Finalmente, considera-se oportuno assumir uma posição objetiva e clara a respeito do discurso de Jesus. Pensa-se que a realidade concreta econômica, social e política da Palestina, no início do século I, denotava, além da violência, profundas desigualdades relativas à economia, à sociedade, à política e à religião, conforme a mesma era realizada no Templo. Evidentemente, para Cristo nada do contexto assinalado passou desapercebido, porquanto, Ele questionou todo o quadro histórico do período em que viveu, incluindo a religião, conforme era desenvolvida naquele tempo.

Portanto, ficou muito claro que o seu discurso visava, fundamentalmente, o que ocorria com as classes submissas e exploradas, representadas por mendigos, desempregados, escravos, proletários das esferas urbana e rural que recebiam parcos salários e pequenos proprietários. Nota-se que este segmento de humanidade era excluído ou vivia em extrema penúria. Na verdade, foram eles os principais ouvintes e acompanhantes de Cristo, no decurso da sua pregação, pelos territórios 
palestinos. Além disso, não se pode ignorar a preocupação de Cristo, em relação aos enfermos, aos deficientes físicos e mentais, aos prisioneiros sem causa, claramente, válida e discutida, aos injustamente perseguidos pelos mais variados motivos e razões e, que permaneciam completamente à mercê da sua própria sorte, uma vez que, a justiça não os alcançava.

Apesar de se reconhecer o seu discurso, cujo conteúdo deixou um grande legado referente ao que seja a bondade, a justiça e a paz, não é menos verdade, por outro lado, que quando foi necessário, Cristo tomou uma atitude taxativa, como foi no caso dos mercadores do Templo, que tiveram as suas bancas por Ele viradas, além de terem recebido chicotadas. Nesta oportunidade, Cristo considerou que as pessoas já tinham ultrapassado todos os limites, tornando um lugar mercantil, o Templo que Ele considerava a moradia do Pai, na terra.

Assim sendo, concorda-se com o discurso radical de Cristo e, transpondo-o para a realidade do século XXI, pondera-se que, se as políticas públicas das nações tivessem como suporte, as recomendações expressas na mensagem de Cristo, a condição humana e social dos povos estaria, sem dúvida, em um patamar muito mais desenvolvido do que se verifica nos tempos atuais.

Finalmente, se os nossos governantes tivessem a visão plena da justiça social, o Brasil viveria, no presente, uma outra realidade, pois, os brasileiros estariam assistidos dignamente, no que tange à educação, à saúde, ao saneamento básico, à moradia, aos transportes urbanos e à segurança. Haveria maior alegria e felicidade do que estas palavras encerram?

Chega-se, então, à questão central de toda a trajetória percorrida, ao longo deste trabalho: o que verdadeiramente transforma o mundo são as ideias. E, quando uma ideia é superada, será substituída por outra ideia inovadora que será a responsável por novas mudanças que trarão novas realidades.

\section{REFERÊNCIAS}

BARBAGLIO, G. Jesus, Hebreu da Galileia: pesquisa histórica. (Coleção Cultura Bíblica). Tradução: Walter Eduardo Lisboa. São Paulo: Paulinas, 2011.

. Maria nel Nuovo Testamento. In: Leonardi, C.; Degl'Innocenti, A., eds. Maria. Virgine Madre Regina. p. 7-20. Roma, 2000.

BERGER, K. Jesus Als Naziräer/Nasiräer. In: NT 38, p. 323-335. 1996.

BÍBLIA SAGRADA. Revisão e Atualização das Introduções, Livros principais, Notas e Índices. São Paulo: Stampley Publicações Ltda, 1971-72.

BÍBLICA: O Atlas da Bíblia: uma viagem histórica e social pelas terras bíblicas. Consultor chefe: Barry J. Beitzel. Tradução: Mathias de Abreu Lima Filho, Eliana Chiochetti e Rodrigo Popotic. Barueri: Girassol, 2009.
BLINZER, J. I Fratelli e le Sorelle di Gesù. Brescia: Paideia, 1974.

BROWN, R. E. La Nascita del Messia Secondo Matteo e Luca. Assisi: Cittadella, 1981.

CARROLL, J. Jerusalém, Jerusalém: como a história da antiga cidade sagrada para três grandes religiões deu início ao mundo moderno. Tradução: Euclides Luiz Calloni, Cleusa Margô Wosgrau. São Paulo: Cultrix, 2013.

DA SPINETOLI, O. Il Vangelo del Natale. Roma: Borla, 1996.

FIRPO, G. Il Problema Cronologico dela Nascita di Gesù. Brescia: Paideia, 1983.

FOERSTER, W. Iesous. In: GLNT IV, 909-934.

FORABOSCHI, D. Tra Guerra, sfruttamento e sviluppo: L'economia dela Palestina (I a.C.- I d. C.). In: Sacchi, P., ed. Il Giudaismo Palestinese: dal 
I secolo a.C. al I Secolo d.C. p. 123-136. Bologna: Fattoadarte, 1993.

HOUTART, F. Religião e Modos de Produção PréCapitalistas. Tradução: Álvaro Cunha. Revisão: Luiz Antônio Miranda. São Paulo: Edições Paulinas, 1982.

JEREMIAS, J. Jerusalem in the Time of Jesus. Filadélfia: Fortress Press, 1978.

JOSEFO, F. História dos Hebreus. Tradução: Vicente Pedroso. Rio de Janeiro: Casa Publicadora das Assembleias de Deus, 2015.

LAURENTIN, R. Les Évangiles de L'Enfance du Christ. Vérité de Noël au-de-là des Mythes. Paris, 1982.

LÜDEMANN, G. Virgin Birth? The Real Story of Mary and her Son Jesus. London, 1998.

MEIER, J. P. Um Judeu Marginal. Repensando o Jesus Histórico, I. p. 205-426. Rio de Janeiro: Imago, 1993.

MERKLEIN, H. Die Jesusgeschichte - synoptisch gesehen. p. 33 ss. Stuttgart, 1994.

MEYERS, E. M. Jesus und Seine Galiläische Lebenswelt. In: ZNT 1, p. 27-39. 1998.
O'NEIL, J. C. Jesus of Nazareth. JThSt 50, p. 135-142. 1999.

PESCH, R. Zur Frage der Brüder und Schwestern Jesu. In: Das Markusevangelium. I. p. 322-324. Freiburg-Basel-Wien, 1976.

PORTER, S. E. Jesus and the use of Greek in Galilee. In: Chilton: Evans, eds. Studying the Historical Jesus. p. 123-154. Leiden: Brill, 1994.

RHYMER, J. Os Povos da Bíblia. Tradução: Barbara Theoto Lambert. São Paulo: Melhoramentos, 1995.

SACCHI, P. Riflessioni sul Problema Della Formazione Culturale di Gesù. In: Henoch 14, p. 243-260. 1992.

SÖDING, T. "Was Kann aus Nazareth Schon Gutes Kommem?" (Joh 1, 46). Die Bedeutung des Judenseins Jesu im Johannesevangelium. In: NTS 46, p. 21-41. 2000.

VON SODEN, H. Chronology. In: Encyclopaedia Biblica. I. London: Black, 1899.

ZWICKEL, W. Atlas Bíblico. Tradução: Renatus Porath. São Paulo: Paulinas, 2010. 